Georgetown University Law Center Scholarship @ GEORGETOWN LAW

1992

\title{
The Sound of Silence: Default Rules and Contractual Consent
}

Randy E. Barnett

Georgetown University Law Center, rb325@law.georgetown.edu

This paper can be downloaded free of charge from:

https://scholarship.law.georgetown.edu/facpub/1255

78 Va. L. Rev. 821-911 (1992)

This open-access article is brought to you by the Georgetown Law Library. Posted with permission of the author. Follow this and additional works at: https://scholarship.law.georgetown.edu/facpub

Part of the Constitutional Law Commons, and the Contracts Commons 


\title{
THE SOUND OF SILENCE: DEFAULT RULES AND CONTRACTUAL CONSENT
}

\author{
Randy E. Barnett*
}

... I had grasped the significance of the silence of the dog, for one true inference invariably suggests others. . . Obviously the midnight visitor was someone whom the dog knew well.

-Sherlock Holmes ${ }^{1}$

\section{INTRODUCTION: INCOMPLETE CONTRACTS AND CONSENT}

$\mathbf{B}^{\mathrm{r}}$ $Y$ now everyone acknowledges the legal realist insight that all contracts are, by necessity, incoinplete to some degree. The inevitability of incompleteness reflects, to borrow a distinction from H.L.A. Hart, both our "relative ignorance of fact" and "our relative mdeterminacy of aim."2 These two causes of contractual incomplete-

* Norman \& Edna Freehling Scholar and Professor of Law, Illinois Institute of Technology, Chicago-Kent College of Law. The analysis presented here grows out of a presentation given to the Contracts Section of the Association of American Law Schools as part of a panel on "Default Rules and Contract" held at the 1991 Annual Meeting in Washington D.C. An earlier version of this Article was presented at faculty workshops at Emory University School of Law and Nova University Center for the Study of Law. Many persons have generously provided very helpful comments on earher drafts, soine of which were unusually comprehensive and detailed. They are Ian Ayres, Anita Bernstein, Steven Burton, Jacob Corre, Richard Craswell, Richard Epstein, Mark Gergen, Thomas Hudson, Lawrence Kalevitch, Todd Rakoff, Carol Rose and Charles Silver. Craig Truitt rendered invaluable research assistance. Finally, I wish especially to thank Richard Craswell for imitially challenging me to develop further my theory of contract, and the students in iny 1990-91 contracts class at Northwestern Umiversity School of Law for inspiring me to meet his challenge. Financial support for this project was provided by the Marshall D. Ewell Research Fund of the Chicago-Kent College of Law.

12 Arthur Conan Doyle, Silver Blaze, in The Annotated Sherlock Holmes 261, 280 (William S. Baring-Gould ed., 1967). See Douglas G. Baird, Self-Interest and Cooperation in Long-Term Contracts, $19 \mathrm{~J}$. Legal Stud. 583, 593 (1990) ("We can draw an inference from silence, just as Sherlock Holmes can draw an inference from a dog that did not bark.").

2 H.L.A. Hart, The Concept of Law 125 (1961). 
ness reflect in turn two fundamental problems addressed by liberal principles of justice: the problems of knowledge and of interest. ${ }^{3}$

Parties drafting a contract confront a serious knowledge problem. Because they cannot foresee every future event or know precisely how their own purposes may change, they cannot negotiate terms specifically to cover all contingencies. As a result, their inanifested agreement will be silent as to these matters. As the duration of a contract is extended, the knowledge problem facing the parties is likely to increase and the completeness of their agreement to decrease.

Incompleteness of contracts is also a function of the parties' interests. Settling in advance even those contingencies that can be foreseen is costly. Many foreseeable contingencies, given their low probability, are better left unnegotiated ex ante im the hopes that they will not materialize or will be handled cooperatively ex post if they do. And strategic considerations may lead one or both parties to reinain silent about a particular issue. ${ }^{4}$

The received wisdom concerning contractual incoinpleteness is reffected in the concept of "gap-filler," a legal realist term that has dominated contract discourse for several decades. According to this view, no contract is without its "gaps." Much of what is taught as the law of contract can be conceived as publicly provided "background" rules or principles that fill the inevitable gaps in the private law inade by contracting parties.

This gap-filling conception of contract law has tended to undermine support for consent as the basis of contractual obligation. Gap-filling terms-soinetimes referred to as "implied-in-law"-are said to be imiposed by the legal system for reasons of principle or policy rather

3 See infra Part I. For a more general discussion of these problems and how they are addressed by the liberal conception of justice and the rule of law, see Randy $E$. Barnett, The Function of Several Property and Freedom of Contract, 9 Soc. Phil. \& Pol'y 62 (1992) [hereinafter Barnett, Function of Property]; Randy E. Barnett, Foreword: Can Justice and the Rule of Law Be Reconciled?, 11 Harv. J.L. \& Pub. Pol'y 597 (1988) [hereinafter Barnett, Justice \& the Rule of Law].

4 Ian Ayres and Robert Gertner summarize this reason for silence as follows:

One party might strategically withhold information that would increase the total gains from contracting (the "size of the pie") in order to increase her private share of the gains from contracting (her "share of the pie").

Ian Ayres \& Robert Gertner, Filling Gaps in Incomplete Contracts: An Economic Theory of Default Rules, 99 Yale L.J. 87, 94 (1989). For an expanded analysis of this matter, see Jason S. Johnston, Strategic Bargaining and the Economic Theory of Contract Default Rules, 100 Yale L.J. 615 (1990). 
than consented to by the parties. That such implied-in-law terms are based on the parties' consent has long been thouglit to be pure fiction. ${ }^{5}$ If the publicly provided rules of contract law alınost always operate where there is a gap in the manifestation of assent, then consequently a gap-filling provision must be coercively imposed on parties who lave not, by assumption, consented to its imposition. Furtliermore, if the central problem of contract theory is to decide how gaps in inanifested assent sliould be filled, then the consent of the parties plays no role in the choice of gap-fillers. In this manner, the pervasiveness of contractual incompleteness and the concept of gapfillers makes consent look quite irrelevant to the main issues of contract theory. ${ }^{6}$

That this is the prevailing wisdom of contract theory is evidenced by the fact that scholars as disparate as Ian Macneil, ${ }^{7}$ Subha Narasimhan, ${ }^{8}$ and Charles Fried ${ }^{9}$ adliere to it. Recently, lowever, in an almost imperceptible shift, the rletoric of gap-filling has been mcreasingly supplanted by a new and powerful heuristic device: the

5 See, e.g., Peter Linzer, Uncontracts: Context, Contorts and the Relational Approach, 1988 Ann. Surv. Am. L. 139, 173, n.188 ("I recognize the fiction involved in speaking of an impliedin-law covenant 'existing'; I apologize to legal realists for my shorthand terminology.").

6 See, e.g., id. at 142 ("When rights and obhigations cannot be traced to an express contract, but instead relate back to an informal and often long-term relationship, or when an express contract is adhesive, it is difficult to find real consent to the duties imposed by courts or by legislatures.").

7 See Ian R. Macneil, Commentary, Restateinent (Second) of Contracts and Presentiation, $60 \mathrm{Va}$. L. Rev. 589, 593 (1974) ("When the guise of . . . consensually formed law was not possible, ... the system filled the gaps by supplying presentiation in the form of predictable and theoretically precise rules."). Macneil's views of consent are rather coinplex and, in iny view, somewhat ambiguous if not ambivalent. For a detailed analysis, see Randy E. Barnett, Conflicting Visions: A Critique of Ian Macneil's Relational Theory of Contract, 78 Va. L. Rev. (forthcoming August 1992).

${ }^{8}$ See Subha Narasimhan, Of Expectations, Incomplete Contracting, and the Bargain Primciple, 74 Cal. L. Rev. 1123, 1179 (1986) ("Once mcomplete allocation [by a contract] is conceded, we must either limit enforceinent to what parties actually consented to or impose allocations based on nonconsensual factors as a matter of legal duty." (emphasis added) (footnote omitted)). In the omitted footnote, Narasimhan suggests as sources of these legal duties such nonconsensual factors as "the nced for contractual stability, economic efficiency, or minimizing hitigation." Id. at 1179 n.151.

9 See Charles Fried, Contract As Prounise (1981):

In all these cases [of unallocated risks] the court is forced to sort out the difficulties that result when parties think they have agreed but actually have not. The one basis on which these cases cannot be resolved is on the basis of the agreement-that is, of contract as promise.

Id. at 60 . 
concept of default rules. This concept has been employed by an ideologically diverse group of contract theorists includimg Ayres and Gertner, ${ }^{10}$ Goetz and Scott, ${ }^{11}$ Coleman, Heckathorn, and Maser, ${ }^{12}$ Haddock, Macey, and McChesney, ${ }^{13}$ and even soine scholars who have failed to overcoine the transaction costs of forming a writing partnership, such as Douglas Baird, ${ }^{14}$ David Charny, ${ }^{15}$ Richard Craswell, ${ }^{16}$ Richard Epstein, ${ }^{17}$ Clayton Gillette, ${ }^{18}$ and Jason Johnston. ${ }^{19}$

The default rule approach analogizes the way that contract law fills gaps in the expressed consent of contracting parties to the way that word-processing programs set our margins for us in the absence of our expressly setting them for ourselves. A word-processing program that required us to set every variable needed to write a page of text would be inore trouble than it was worth. Instead, all word-processing programs provide default settimgs for such variables as margins, type fonts, and line spacing and leave it to the user to change any of these default settings to better suit his or her purposes. ${ }^{20}$

10 See Ayres \& Gertner, supra note 4; Ian Ayres \& Robert Gertner, Strategic Contractual Inefficiency and the Optimal Choice of Legal Rules, 101 Yale L.J. 729 (1992).

11 See Charles J. Goetz \& Robert E. Scott, The Limits of Expanded Choice: An Analysis of the Interactions Between Express and Imphed Contract Terms, 73 Cal. L. Rev. 261 (1985); Robert E. Scott, A Relational Theory of Default Rules for Commercial Contracts, 19 J. Legal Stud. 597 (1990).

12 See Jules L. Coleman, Douglas D. Heckathorn, \& Steven M. Maser, A Bargaining Theory Approach to Default Provisions and Disclosure Rules in Contract Law, 12 Harv. J.L. \& Pub. Pol'y 639 (1989).

13 See David D. Haddock, Jonathan R. Macey, \& Fred S. McChesney, Property Rights in Assets and Resistance to Tender Offers, 73 Va. L. Rev. 701 (1987). This article exemphifes the now pervasive use of default rule terminology in the corporate legal theory hiterature where, I beheve, it originated before spreading to contract theory.

14 See Baird, supra note 1.

15 See David Charny, Hypothetical Bargains: The Normative Strncture of Contract Interpretation, 89 Mich. L. Rev. 1815 (1991).

16 See Richard Craswell, Contract Law, Default Rules, and the Philosophy of Promising, 88 Mich. L. Rev. 489 (1989).

17 Richard A. Epstein, Beyond Foreseeability: Consequential Danages in the Law of Contract, 18 J. Legal Stud. 105 (1989).

18 See Clayton P. Gillette, Commercial Relationships and the Selection of Default Rules for Remote Risks, 19 J. Legal Stud. 535 (1990).

19 See Johnston, supra note 4.

20 Indeed, Wordstar, the first widely popular word-processing program, required the user installing the program to spend a great deal of tine selecting most of the default settings by which the program would operate. In part because of the inconvenience cansed by the absence of enough default rnles, other programs have supplanted Wordstar in popularity. These other programs do not impose upon the user the need to make so inany decisions, but instead provide the default settings that the prograin authors beheve inost users would desire. We 
What makes the default rule approach to gap-filling distmctive im both word processing and contract law is that default rules are binding in the absence of manifested assent to the contrary-which means that a manifested assent to the contrary will displace the default rule. Any gap-filling rule that cannot be displaced by manifested assent is not properly called a default rule at all, but is what Ayres and Gertner have called an "immutable" rule-that is, some other kind of contract law background norm that may fill a gap in assent or may even displace the manifested assent of the parties. ${ }^{21}$

By this criterion, many of the provisions of Article 2 of the Uniform Commercial Code (U.C.C.) are default rules, because they apply "unless otherwise agreed."22 Eighteen of the twenty-eight provisions of Part 3 of Article 2, which specify the "General Obligation and Construction of Contract," contaim this or comparable language..$^{23}$ Moreover, section 1-102(4) specifies that "[t]he presence im certain provisions of this Act of the words 'uuless otherwise agreed' or words of similar import does not imply that the effect of other provisions may not be varied by agreement under subsection (3)."24 The default rule approach is not, of course, limited to the U.C.C. Outside the areas of fraud, duress, and unconscionability, few of the cases in law school casebooks would have arisen had the parties imcluded an express clause in their agreement to govern the problem that arose

would hardly say that the programmers providing the default settings are inposing their will on users. On the contrary, they are providing a service to users by performing a task which users would rather not perform themselves. The absence of default rules or the inclusion of the wrong default rules thus creates an imposition on those who use a word-processing program.

21 See Ayres \& Gertner, supra note 4, at 87 ("Default rules fill the gaps in incomplete contracts; they govern unless the parties contract around them. Immutable rules cannot be contracted around; they govern even if the parties attempt to contract around them.").

22 This language is found at least once and in some instances more than once in 25 of the 97 non-definitional seetions of Article 2. See U.C.C. $\S \S 2-210,2-306$ to -312, 2-319 to -327, 2-503 to $-504,2-507,2-511,2-513$ to $-514,2-601,2-706$ (1987). Comparable language is found in eight additional seetions. See U.C.C. $\$ \S 2-206,2-207,2-314,2-315,2-401,2-501,2-509,2-718$ (1987). Comparable language is also to be found in the official comments to three additional seetions. See U.C.C. $\S \S 2-608,2-614,2-615$ (1987).

23 See U.C.C. $\$ \S 2-306$ to $-312,2-314$ to $-315,2-319$ to -327 (1987).

24 U.C.C. $\$ 1-102(4)$ (1987). The U.C.C. also states that:

The effect of provisions of this Act may be varied by agreement, except as otherwise provided in this Act and except that the obligations of good faith, diligence, reasonableness and care prescribed by this Act may not be disclained by agreement but the parties may by agreement determine the standards by which the performance of such obligations is to be measured if sucl standards are not manifestly unreasonable.

Id. at $\S 1-102(3)$. 
between them. In almost every case, the silence of the parties creates a gap that the default rules of contract law are used to fill.

The rhetoric of default rules is in the process of becoming the terminology of choice for contract theorists. ${ }^{25}$ Yet the imphications of this subtle conceptual shift for the debate concerning the underlying basis of contractual obligation-especially the role of consent-have yet to be explored. The idea of filling gaps in manifested consent with default rules calls imto question the neat dichotomy between terms that are assented to and those that are imposed by the legal system. It suggests yet another category of terms that, although supphed ${ }^{26}$ by courts or legislatures when there is a gap im manifested assent, nonetheless reflect the consent of the parties.

Terms supphed by default rules are not a product of the expressed or imphed-m-fact consent of the parties as these two notions have traditionally been understood, and may therefore be considered genuinely implied-in-law. But neither are terms supplied by default rules invariably inposed on the parties by the legal system for reasons of principle or pohicy as are terms supphed by immutable contract rules or by tort law. In a very real sense, such terms can be and often are indirectly consented to by parties who could have contracted around them-but did not.

In this Article, I want to challenge the received wisdoin of "gapfilling in the absence of consent" by showing how the concept of default rules bolsters the theoretical importance of consent. I will accoinphish this by expanding and refining my analysis of a "consent theory of contract."27 I propose that the concept of default rules

25 See, e.g., Beth A. Eisler, Default Rules for Contract Formation By Promise and the Need for Revision of the Mailbox Rule, 79 Ky. L.J. 557 (1990-91); Alex Y. Seita, Uncertainty and Contract Law, 46 U. Pitt. L. Rev. 75, 122-32 (1984).

26 The term "supplied," rather than "implied-in-law" is favored by the Restatement (Second) of Contracts and by Allan Farnsworth. See E. Allan Farnsworth, Contracts $\S 7.16$, at 546 (2d ed. 1990) ("The process by which a court supplies a term is often called "implication." " (emphasis added)). In a footnote he elaborates:

The process by which the court derives its conclusion might better be described as "inference," but "miplication" is generally used. Restatement Second $\S 204$ avoids the use of either term: "a term which is reasonable in the circumstances is supplied by the court." The process is sometimes also referred to as "gap filling."

Id. $\$ 7.16$, at $546 \mathrm{n.12}$.

27 I have developed a consent theory of contract in Randy E. Barnett, Contract Scholarship and the Reemergence of Legal Philosophy, 97 Harv. L. Rev. 1223 (1984) (reviewing E. Allan Farnsworth, Contracts (lst ed. 1982)); Randy E. Barnett, A Consent Theory of Contract, 86 
reveals consent to be operating at two distinct levels of contract theory. First, the presence of consent to be legally bound is essential to justify the legal enforcement of any default rules. Second, nested within this overall consent to be legally bound, consent also operates to justify the selection of particular default rules.

With consent operating on both of these levels, contract terms supplied by default rules can be seen to occupy a previously undifferentiated middle ground between the traditional categories of imphed-mfact and implied-in-law terms. Under certain circumstances, it is not at all fictitious to cliaracterize a clioice to remain silent and let default rules operate as an expression of consent, albeit a inore inclioate or indirect expression than wliat we associate with expressed or impliedin-fact terms. ${ }^{28}$ And, even when parties cannot be said to liave consented by their silence to the enforcement of particular default rules, enforceinent may still be justified on tlie grounds of consent when default rules are cliosen to reflect the commonsense or conventional understanding of most parties.

As will become apparent, the concept of default rules entails a very practical implication for low contract law is tauglit im law school. We should replace the traditional dichotomy of expressed or impliedin-fact contract terms that are "really" consented to and implied-inlaw contract terms that are "really" imposed on the parties with a more realistic trichotoiny. In the first category are terms that are a product of direct consent (expressed or implied-in-fact terms), in the second are terms that are a product of indirect consent (implied-inlaw default rules), and in the third are terms that are inposed upon

Colum. L. Rev. 269 (1986) [hereinafter Barnett, Consent Theory]; Randy E. Barnett, Contract Remedies and Inalienable Rights, 4 Soc. Phil. \& Pol'y 179 (1986) [hereinafter Barnett, Inalienable Rights]; Randy E. Barnett, Squaring Undisclosed Agency Law with Contract Theory, 75 Cal. L. Rev. 1969 (1987) [hereinafter Barnett, Undisclosed Agency]; Randy E. Barnett, The Internal and External Analysis of Concepts, 11 Cardozo L. Rev. 525 (1990) [hereinafter Barnett, Internal \& External Analysis]; and Randy E. Barnett \& Mary E. Becker, Beyond Reliance: Promissory Estoppel, Contract Formalities, and Misrepresentations, 15 Hofstra L. Rev. 443 (1987). A condensed and revised account of this approach appears in Randy E. Barnett, Rights and Remedies in a Consent Theory of Contract, in Liability and Responsibility: Essays in Law and Morals 135 (R.G. Frey \& Christopher W. Morris eds., 1991).

28 For a discussion of why expressed consent is "real" consent, see infra Part IV. 
the parties without any consent (implied-in-law immutable terms). ${ }^{29}$ Witl this reconfiguration, the set of implied-in-law terms that represent a genuine imposition on the parties is unuch sinaller than is coinmonly assuined.

In Part I, I elaborate in soine detail on the essential social functions that consent plays in the liberal conception of justice and the rule of law. I discuss liow the consensual element of contract that comprises the liberal primciple of freedom of contract addresses the pervasive social problems of knowledge and of interest. Freedom of contract entails botli freedom to contract-tlre power to effect one's legal relations by consent-and freedom from contract-tlie immuinty froin having one's rights to resources transferred witlout one's consent. Working togetlier, tliese two components of contractual freedom liarness the personal and local knowledge possessed by individuals and associations by enabling tliem to put their own knowledge into action while taking into account the vast knowledge possessed by others of whicl1 they are necessarily ignorant. Moreover, these components of contractual freedom also address the problem of interest by providing incentives botli to use the knowledge in one's possession and to take into account the knowledge of otliers.

In Part II, I use this functional analysis of consent to explain the important justificatory role played by manifestations of consent. I show low, by manifesting their intention to be legally bound, contracting parties are implicitly coimmitting themselves to the jurisdiction of a legal system that is thereby justified in using tlie background rules of contract law to fill the gaps in their agreeinent. Under certain circumstances, this "consent to jurisdiction" wonld also justify the enforceinent of any promulgated set of defanlt rules. In suin, a consent to be legally bound provides a necessary but only sometimes sufficient justification for enforcing wliatever set of default rules may be promulgated by a legal system.

In Part III, I argue tliat, within a consent tlieory of contract, silence can be meaningful and that its meaning should influence our choice of default rules when the circuinstances described in Part II are absent. I defend my "consent theory of contract" against Ricliard

29 I shall suggest, however, infra text accompanying notes 218-25, how a competitive legal order could transform even implied-in-law immutable rules of contract into genuinely consentbased background rules. 
Craswell's recent criticism that, whatever other justificatory virtues it may have, a consent theory of contract cannot assist in selecting among possible default rules. ${ }^{30}$ In particular, I show how a consent theory provides two coinpelling reasons to choose default rules that reflect the conventional or commonsense understanding existimg im the relevant community of discourse. First, conventionalist default rules are likely to reflect the tacit subjective agreenent of the parties and thereby facilitate the social functions of consent. Second, when parties have asymmetric access to the background rules of contract, enforcing conventionalist default rules will reduce subjective disagreeneents by providing parties who are rationally informed of the background rules with an mcentive to educate those parties who are rationally ignorant of these rules. This, too, facilitates the social functioning of consent. In sum, where a consent to jurisdiction exists but is insufficient to justify the enforceinent of any promulgated set of default rules, consent justifies the enforcement of conventionalist default rules.

In Part IV, I take up the issue of why objective or manifested consent can be considered as "real" or genuine as subjective consent. I discuss how the concept of default rules not only reconciles the idea of gap-fillers with consent as the basis of contractual obligation, but also may justify a more radical change in the legal systein that makes contract law. In particular, it may support a horizontal legal order composed of conipeting legal systems, in contrast to the relatively vertical, nionopotistic legal order we hive in today. Finally, in Part V, I conclude by briefly discussing the difficult methodological problem of determining the commonsense or conventional meaning of silence.

\section{The Social Functions of Contractual Consent ${ }^{31}$}

Contract cannot completely be understood apart from the role it plays in a broader scheme of entitlements. ${ }^{32}$ Entitlenients are con-

30 See Craswell, supra note 16. Craswell attacks from the direction of the "utilitarian" wing of legal realism: law and economics. In Barnett, supra note 7, I apply the analysis presented here to the theory of contract advanced by Ian Macneil from the direction of the "communitarian" wing of legal realist contract theory: relationalism.

31 Comments from Carol Rose and Charles Silver proved especially helpful in revising this Section of the Article.

32 I discuss the nature of a "functional" analysis of concepts in Barnett, Function of Property, supra note 3, at 62-65. Suffice it to say that this methodology views the use of concepts as instrumental to achieving certain ends or goals. I contrast this methodology with 
cepts that enable us to handle the pervasive social problems of knowledge, imterest, and power. Each of these problems is multifaceted and cannot be fully explored here. ${ }^{33}$ I shall confine my discussion to those aspects that bear on the question of contractual consent. ${ }^{34}$ In Section

what I call "abstract" analysis in Barnett, Internal \& External Analysis, supra note 27. I discuss the importance of using multiple modes of analysis to reach conclusions in which we can have confidence in Randy E. Barnett, The Virtues of Redundancy in Legal Thought, 38 Clev. St. L. Rev. 153 (1990) [hereinafter Barnett, Virtues of Redundancy]. Further, I do not consider what, if any, ends may underlie the ends I discuss. I am highly skeptical, however, of the radical dichotomy between consequentialist and moral rights analysis favored by most contemporary analysts. See Randy E. Barnett, Foreword: Of Chickens and Eggs-The Compatibility of Moral Rights and Consequentialist Analyses, 12 Harv. J.L. \& Pub. Pol'y 611 (1989) [heremafter Barnett, Chickens \& Eggs]. As I make clear in these writings, while I view a functional analysis as of inestimable importance to the complete understanding of these concepts, I do not exclude the importance of other quite different modes of understanding as well. Much of iny thinking about the mstrumental use of concepts has been influenced by 1 Stephen Toulmin, Human Understanding (1972).

33 Controversies about a functional analysis can arise at several levels. First, one can dispute the desirability of the ends. Second, one can dispute empirically whether the concepts in question actually facilitate the ends better than some alternative. Third, although a concept may be conceded to facilitate a particular end better than any other, one can assert that, because other ends are also desirable, some modification in the concept in question is warranted, or that it ought to be supplemented by some other concept.

In this Part, I do not purport to present a complete functional analysis of consent. In particular, I assume that, once understood, there will be general agreement that the problems of knowledge and interest require some solution. Some will dispute this. In addition, I do not consider whether other desirable ends would require that the liberal principles that are needed to address the problems of knowledge, interest, and power be supplemented or modified. I assume that these social problems are so pervasive and fundamental that their solution takes priority over other pressing social problems, and, morcover, that other seemingly distinct social problems would be ameliorated substantially if the problems of knowledge and imterest were handled well. I do not, however, defend these assumptions here. Finally, in each of the legal domains that are regulated by the liberal principles of several property and freedoin of contract discussed below, there are highly specialized problems that may argue either for some modification of or some limitation on these general principles. I do not consider such arguments here.

Nonetheless, I believe that the functional analysis presented here is powerful enough to establish at least a basehine in favor of the liberal conception of justice-including the principle of consent in contract-and of the rule of law that will be discussed in this Part. At a minimum, such a basehine justifies imposing a high burden of persuasion on anyone advocating deviating from these principles to show (a) how the pervasive social problems these liberal principles address will be handled satisfactorily under any alternative regime, and (b) how deviations from these principles are, in practice, to be limited to the ones advocated. It may turn out that prudence will strongly argue against deviations from these principles even when they appear deficient, on the grounds that any such slippage will underinine their survival or effectiveness where they are essential.

34 This will unavoidably create some misunderstanding. In particular, since the initial acquisition of property rights precedes their interpersonal transfer, any discussion of a 
A, I consider how contractual consent helps to solve what I call the "first-order problem of knowledge." In Section B, I discuss how contractual consent is necessary to address two problems of interest. In Section C, I explain how the need to handle what I call the "secondorder problem of knowledge" explains the proper functional relationship between objective and subjective conceptions of consent. ${ }^{35}$

\section{A. Using Resources: The First-Order Problem of Knowledge ${ }^{36}$}

Human bemgs confront myriad ways of using physical resources, mcluding their own bodies. Knowledge of the uses to which resources may be put is both radically dispersed anong the persons and associations that comprise a society, and highly contingent upon the particular circumstances facing each person. The problem of a person or association making knowledgeable choices ainong alternative uses of physical resources is compounded by other persons and associations striving to make their own choices based on their own knowledge. This radical dispersion of knowledge gives rise to what I have called the first-order problem of knowledge.

\section{The Limited Accessibility of Personal and Local Knowledge}

The first-order problem of knowledge arises because access to the vast range of knowledge possessed by individuals and associations is restricted. For example, each person has knowledge of his particular situation-including knowledge of his abilities, his interests, his preferences, and his opportumities-but access to this knowledge by

requirement of consensual transfers is beginning in the middle of a longer story. Although I do discuss property briefly where it is unavoidable, I do not, for example, discuss how the principle of first possession-which regulates initial property acquisition and gets the entitlement ball rolling - functions to address the problems of knowledge and interest. For this analysis, see Barnett, Function of Property, supra note 3, at 81-84, 91.

$35 \mathrm{My}$ experience is that readers tend to dwell - often exclnsively-on whatever analysis one chooses to discuss first, in this case the ability of consent to address the problem of knowledge. Thus, the ability of consent to handle other categories of serious social problems such as the problems of interest and of power (each of which is comprised of a number of distinct subproblems) is overlooked and the full functional importance of consent underestimated. Beyond issuing caveats such as this, I see no way of avoiding this since only one issue can be presented at a time.

${ }^{36}$ This Section is adapted, with some substantive revisions, from the relevant portions of Barnett, Function of Property, supra note 3. The functional analysis presented in this Section is developed in a larger work-in-progress and is necessarily a highly truncated account. 
others is extremely limited. ${ }^{37}$ When persons seek to act on the basis of the knowledge in their possession, such action necessarily involves the use of physical resources (including the use of their bodies). Many of these actions will conflict, in the sense that atteinpts by soine to use physical resources to put their knowledge into action will inevitably interfere with the efforts of others to do the same.

No one has placed greater stress on this particular knowledge problem than Friedrich A. Hayek:

The peculiar character of the problem of a rational economic order is determined precisely by the fact that the knowledge of the circumstances of which we must make use never exists in concentrated or integrated form but solely as the dispersed bits of incomplete and frequently contradictory knowledge which all the separate individuals possess. The economic problein of society is thus not merely a problein of how to allocate "given" resources-if "given" is taken to mean given to a single mind which deliberately solves the problem set by these "data." It is rather a problem of how to secure the best use of resources known to any of the inembers of society, for ends whose relative importance only these individuals know. Or, to put it briefly, it is a problem of the utilization of knowledge which is not given to anyone in its totality. ${ }^{38}$

For Hayek, the problem of knowledge does not arise because one person necessarily has "better" information than another (though this inay well be the case). Rather, Hayek poimts to "the dispersed bits of incomplete and frequently contradictory knowledge which all the separate individuals possess." 39 The first-order problein of knowledge unavoidably arises because each person and association of persons possesses knowledge that is inaccessible to others.

The radically dispersed knowledge described by Hayek may be either "personal" or "local," dependimg upon the degree of its accessibility. Individuals have access to their own personal knowledge that

37 I am not speaking now of the source of one's knowledge, which may or may not be "socially determined" according to the current vernacular. I am speaking of the knowledge in one's possession, however acquired, to which others have limited access.

38 Friedrich A. Hayek, Individualism and Economic Order 77-78 (1948) (einphasis added). For additional discussion of the knowledge problein, see Don Lavoie, National Economic Planning: What is Left? (1985) [hereinafter Lavoie, National Planningl; Don Lavoie, Rivalry and Central Planning (1985) [hereinafter Lavoie, Rivalry \& Planningl Thonas Sowell, Knowledge and Decisions (1980).

39 Hayek, supra note 38 , at 77 (emphasis added). 
others necessarily lack. ${ }^{40}$ Only I know what I am thinking and feeling as I write this passage; only I can observe the rooin I am working in from this vantage poimt; only I know that I would now like something to eat. A list of one's personal knowledge would be both endless and impossible to compile. ${ }^{41}$ One's personal knowledge mcludes knowledge of one's personal preferences, to be sure, but it also includes a knowledge of one's physical and emotional needs, one's particular circumstances, and one's opportunities or alternative courses of action. Indeed, it is impossible to enunierate precisely all the types of knowledge each of us possesses, much less the knowledge itself. ${ }^{42}$

In contrast to personal knowledge, local knowledge is knowledge that is publicly accessible, though this access is still quite limited. Instead of being confined to a single person, access to local knowledge is limited to particular associations of persons. A dinner conversation between two people in a crowded restaurant is accessible to both conversants, but not to everyone in the restaurant. Even persons at the next table may be hard-pressed to understand what is being said. Knowledge need not be himited to a few people to be local. Sixty thousand people viewing a football game in a stadiun knowledge of the game in the sense that the rest of the world does not have access to what they can observe about the game in progress. Even if millions more are watching on television, such knowledge would still be local because billions lack access to it.

In sun1, as used here, personal knowledge refers to an individual's knowledge that is maccessible to others. Local knowledge refers to knowledge to which only certain associations of persons have access.

40 Although I have borrowed the term "personal knowledge" from Michael Polanyi, his use of the term differs markedly from mine as do the types of problems his analysis is intended to address. See Michael Polanyi, Personal Knowledge: Towards a Post-Critical Philosophy (1958).

41 Personal knowledge includes a tacit dimension that, as Michael Polanyi has explained, contains "an actual knowledge that is indeterminate, in the sense that its content cannot be explicitly stated." Michael Polanyi, Knowing and Being 141 (1969). The bearing that the reality and pervasiveness of tacit knowledge have on the selection of contract default rules is discussed infra text accoinpanying notes 135-65.

42 One of the differences betwecn this approach and that provided by standard cconomic analysis is that, while the standard account is based exclusively on individual preferences, this approach stresses the personal and local knowledge that leads people to form preferences. Preferences do not just exist, but result froin the panoply of knowledge in possession of persons and associations. And, as will be stressed here, the fact that access to this knowledge is limited helps explain why a legal system ought to adhere to certain principles or norms-im particular, to the principle of consensual transfers. 
These terms refer not to the substance or origin of knowledge, but to the limited access that persons liave to it. This radical dispersion of personal and local knowledge creates what I will call the first-order problem of knowledge. This problem has two aspects or dimensions: First, one must be able to act on the basis of one's own personal knowledge or the local knowledge one lias access to as a member of an association. Second, when so acting one must someliow take into account tlie knowledge of others of whicl eacli person is hopelessly ignorant.

The dispersal of personal and local knowledge can be pictured as a "knowledge glass" that is botlı lialf-full (what each of us knows) and lialf-empty (what eacli of us is ignorant of). The first-order problem of knowledge facing any society is low to put to use the half that is full while at the same time taking into account the lialf that is empty. For persons to survive and flourish im society witl each other, they must be able to develop and act upon tlieir own personal and local knowledge. Their actions, however, are likely to affect others im ways that can scarcely be known. And the first-order problem of knowledge is magnified because what each of us knows and wishes to put into action is dwarfed by our ignorance. Ratler than being lialf-full, eacli of our knowledge glasses contains but a precious drop.

The first step $\mathrm{m}$ addressing this problem is to recognize tliat it is the use, not tlie mere possession, of personal and local knowledge that creates a problem when persons live im society witli others. Only a person's actions, not his or lier knowledge, can interfere with the ability of others to act on the basis of their own knowledge. ${ }^{43}$ Ideally, what is sought is a relational or social order in which tlie use of everyone's knowledge is possible. Altliouglı differing preferences and opinions can lead to conflicting actions, we need not control preferences and opimions themselves to liandle the problem of conflicting action. We need only control actions, and only those actions that impede the ability of otliers to put the knowledge im their possession to good use.

${ }^{43}$ For example, I may know that the grass between our homes needs to be cut, while you know that you need to sleep late. If I cut the grass early in the morning, it is my actions that prevent you from acting on your knowledge. Though our knowledge has led each of us to act in certain ways, in this example, the problem is one of conflicting actions, not conflicting knowledge. 
In sum, to solve the first-order knowledge problem requires only a relational "order of actions," 44 not an order of preferences.

An order of actions requires some scheme in which conflicts annong actions are minimized. Huinan action inust occur during particular periods of time and in particular physical spaces; this imperative is reflected in the term "order" itself. An order of actions initially suggests a schenie of teinporal priority. ("First her actions, then his.") But spatial priority is another dimension of order. ("She acts over here; he acts over there.") Thus, to achieve an order of actions one must regulate the use of physical resources. A relational order of actions is achieved when the mdividual or associational uses of physical resources are teniporally and spatially coordinated so as to reduce or eliminate the possibility that two persons or associations will attempt to use the same resource at the same time. If human actions can be suitably regulated, then we need not attempt to reinold or coordinate personal or local knowledge itself. Not just any relational order will do, however. We want an order of actions in which personal and local knowledge can be developed, disseminated, and acted upon, and some ordering inethods will perform this function better than others.

\section{Two Methods of Attaining a Relational Order of Actions}

Two quite different methods of achieving a relational order of actions are centralized and decentralized ordering. Although both methods are essential to attaining a relational order of actions in any society, they are not equally suited to address the first-order problem of knowledge.

\section{a. Centralized Ordering ${ }^{45}$}

The idea of centralized ordering of society as a whole is both attractive and plausible $\mathrm{m}$ hight of its familiarity. The family is organized in this way, with parents inaking decisions about the disposition of fam-

44 This helpful phrase is Hayek's. See, e.g., 1 Frederick A. Hayek, Law, Legislation and Liberty 96 (1973).

45 The following discussion of centralized ordering is heavily influenced by Hayek. See, e.g., Hayek, supra note 38, at 119-208; F.A. Hayek, New Studies in Philosophy, Politics, Economics and the History of Ideas 232-46. Hayek's analysis and that of others arguing in the same vein is explained and applied in Lavoie, National Planning, supra note 38; and Lavoie, Rivalry and Planming, supra note 38. 
ily assets among the family members. Larger commercial firms are organized this way as well, with a hierarchical association of persons called "management" making decisions about using the resources of the company, subject to the approval of a board of directors. The mihtary, with its extremely well-defined chams of command, is perhaps the paradigm of centralized ordering.

Moreover, centralized ordering is undoubtedly a valuable method of capitalizimg upon both personal and local knowledge. One imdividual actimg as a central director or planner can effectively order the actions of other persons so as to capitatize on the planner's personal knowledge. For example, centralized ordering can harness a parent's personal knowledge of the needs of her child, an entrepreneur's personal knowledge of an unfulfilled demand im a market, or a field officer's personal knowledge of a tactical situation im combat. Or centralized direction can capitalize upon the local knowledge of an association. For example, it can use the local knowledge of a husband and wife, the talented managers of a corporation, or a military command.

Yet, despite its undeniable advantages, centralized ordering is completely unsuited to handle the first-order problem of knowledge. Suppose we delegated to some person or association the responsibility for coordmating resource use in accordance with the diverse knowledge of all persons and associations in society. To achieve an overall order of actions with such a strategy, some person or identifiable set of persons would somehow have to (a) obtain the personal and local knowledge of all persons and associations, (b) incorporate this knowledge imto a coherent or coordinated plan of human actions, and (c) transmit instructions on resource use consistent with this plan to everyone in the society so that persons could act accordingly. Intractable problems arise at each step in this process.

The very strength of centrahzed direction in capitahimg on the personal and local knowledge of central directors is at once its weakness as a strategy for solving the first-order problem of knowledge. Centratized ordering is especially effective when those im charge of the ordering scheme have access to useful personal or local knowledge. But, although central directors have access to their own personal and local knowledge, they plainly lack access to the ever-changing totahty of personal and local knowledge dispersed throughout an entire society. 
In sum, centralized direction cannot solve the first-order problem of knowledge in society at large because central directors cannot possibly have access to the personal and local knowledge that such an ordering strategy requires. They are hopelessly ignorant of the knowledge needed to achieve an order of actions that would permit persons to put to use their personal and local knowledge. Moreover, they lack the capacity to integrate the necessary knowledge into a coherent plan and to communicate to all their allocated roles. Together, the three essential elements required by a centralized ordering strategy are nonexistent when this method is apphied to govern resource use in an entire society. In this regard, the innpossibility of central planning or true sociahsm stems not from the impossibility of centralized direction simpliciter, but from the impossibihity of using centralized direction writ large to handle the first-order problem of knowledge. It is for this reason that centrally-planned economies have, without exception, failed niserably to serve the public welfare. ${ }^{46}$

\section{b. Decentralized Ordering}

How could the first-order problem of knowledge possibly be addressed by anything except central direction without immediately descending into chaos or disorder? The answer involves the concept of jurisdiction. A jurisdictional strategy attempts to handle the firstorder problem of the radical dispersion of personal and local knowledge by using the idea of "bonnded individual and associational discretion." This method of social ordering defines a jurisdiction or domam within which an mdividual or association is free to act on the basis of personal and local knowledge.

Implicit in this jurisdictional strategy is a crucial distmction between the judgment maker and the judgment to be made. To use the langnage of American sports, such a strategy distinguishes the jurisdictional question, "who makes the call?" from the substantive question, "what is the correct call?"47 To answer each question

46 Some have persuasively argued that a completely centrally-planned economy is an impossibility. See authorities cited supra note 38 . What are called centrally-planned economies are actually mixed economies that merely rely more heavily than others on central planning. At a mimimum, such economies require a functioming black market.

47 The phrase "making the call" in American sports derives from baseball umpires who are said to "call" whether a pitch is a ball or a strike. So we could distinguish the question of who it is that is to make the call-the umpire-from the question of the correct call to make-a ball or a strike. 
requires substantially different knowledge. Answering the second question requires personal and local knowledge of particular circumstances-knowledge that is inaccessible to centralized mechanisms. Answering the first question requires only that we know who is in the best position to have this knowledge.

This quality of "being in the best position to know" is one important aspect of institutional or personal competence. The knowledge needed to answer the second of these questions differs substantially from that needed to answer the question of competence. Even when we do not know the correct call, we may know who is most likely to have the knowledge that such a call requires. Instead of gaming access to the personal and local knowledge needed to inake the decision in question, such an assessment requires only that we determine who is in the best position to obtain this knowledge. In baseball, for example, we may know that the uinpire is in the best position to assess whether or not a pitched ball is in the strike zone without knowing anything about a particular pitch. ${ }^{48}$

The earlier discussion of personal and local knowledge suggests that individuals and associations have a comparative advantage over centrahzed mechanisms. ${ }^{49}$ They have access to types of knowledge that centrahized mechanisms lack. The fact that imdividual persons and institutions are generally in the best position to make the right call does not, however, mean that they will always make good use of their access or that others are never in a better position to make a particular call. Nor does it mean that an analysis of personal and institutional competence would never benefit from a substantive assessment of the right call to make. We inay, in fact, bolster our assessment of personal and institutional competence by sampling a few decisions to see if they appear to reflect the knowledge we expect these persons and institutions to possess. A pattern of egregious decisions would call into question the competence of the decision maker.

48 Actually, both the umpire and the catcher are in an equally good position to make the call, so from the perspective of the first-order problem of knowledge the allocation of jurisdiction is a draw. But the umpire and the catcher have different interests-specifically, the umpire is ordinarily more capable of rendering an impartial decision than the catcher. I briefiy discuss the problem of interest, and the partiality problem in particular, infra text accompanying notes $65-69$.

49 Bear in mind that I am speaking now of an entire society. The previous Section should have made it clear that institutions with contralized direction-e.g., the family, businesses, schools, and other organizations--perform important functions within a decentralized society. 
Still, the possibility of second-guessing the decisions of those in the best position to inake a call does not change the basic analysis. Given that no decision inaker is perfect, we need to make a comparative and generalized judgment when determining the appropriate jurisdictional allocation. A persistent bias in favor of centralized decision making results from an apparent ability to second-guess the wisdoin of the decisions of others on occasions when these decisions go awry. Such a bias is an instance of the fallacy of the whole. It falsely assumes that what is unquestionably true about individual decisions-that others can soinetimes know better-is also true of systeinatic decision making - that others are inore competent generally. An institutional competence to second-guess the correctness of another's call on occasion does not entail an institutional coinpetence to make correct calls for others systematically. The concept of competence does not rest on an ability to make every decision better than anyone else; it rests on being in a better position than anyone else to make knowledgeable decisions.

The idea of jurisdiction based on "bounded individual and associational discretion" is, of course, far too general to define actual conduct as permissible or subject to prohibition. It says nothing about the nature of the domain or the extent of the boundary. Nonetheless, even at this extreinely general level, such a strategy is theoretically revealing in several ways. First, it identifies discretion-or biberty-as a means of capitalizing on knowledge that cannot be transmitted through a chain of command to central directors. Second, it gives discretion to individuals, who are most likely to possess personal knowledge, and to associations, which are most likely to possess local knowledge. Fimally, it immediately suggests that discretion must somehow be bounded, albeit in a manner that does not undermme the purpose for adopting the strategy. The boundaries of this discretion are defined by two distinct conceptual components: (a) decentralized jurisdiction over physical resources, and (b) consensual transfers of these jurisdictions. Both concepts are reflected in the liberal conception of justice.

\section{The Liberal Conception of Justice}

The hiberal conception of justice represents a two-part approach to the first-order problem of knowledge. First, it recognizes the jurisdictions of diverse individuals and associations over physical resources so 
as to permit them to act on the basis of their own personal and local knowledge. Second, it allows the transfer of a person's or association's jurisdiction only with its manifested consent. This permits changes in jurisdictions to reflect changes in knowledge, while making possible a price system that enables persons to take the knowledge of others into account when deciding how to act.

The hiberal conception of justice regulates the use of force in society by the concept of entitlements or rights. The first part of the strategy-decentralized jurisdiction-is reflected in the nature and scope of these rights. Within the classical liberal approach, the rights that concern jurisdiction over physical resources are called property riglits. To liave property in a pliysical resource-including one's body-means that one is free to use this resource in any way one chooses provided that this use does not infringe upon the rights of others.

Because this concept of property protects the discretionary use of resources by private persons, as opposed to government officials, this idea is often referred to as "private property." For present purposes, however, I prefer "several property," a term also favored by Friedrich A. Hayek and the figures of the Scottish enlightenment. ${ }^{50}$ The term several property inakes it clearer that jurisdiction to use resources is dispersed among the "several"--meaning "diverse, many, numerous, distinct, particnlar, or separate"s1_-persons and associations that comprise a society, rather tlian being reposed in a monohithic, centralized institution.

The second part of the strategy-consensual transfers only-is reflected in the concept of "freedom of contract." Freedom of contract is coinprised of two distinct principles: freedom to contract ${ }^{52}$ and

so See, e.g., Hayek, supra note 44, at 121 .

51 The Oxford English Dictionary identifies one meaning of "several" as "[e]xisting apart, separate" and a second meaning as "[p]ertaiming to an individual person or thing." As a special instance of the second meaning it gives the following: "Chiefly Law. (Opposed to common.) Private; privately owned or occupied." The Oxford English Dictionary 97 (2d ed. 1989).

52 Ian Macneil refers to this aspect as the "power of contract." See Ian R. Macneil, Power of Contract and Agreed Remedies, 47 Cornell L.Q. 495 (1962):

Power of contract is one of the two sides of freedom of contract. On one hand, freedom of contract is a freedom from restraint, an immunity froin legal reprisal for making or receiving promises. On the other hand, it is not really a freedom of contract, but a power of contract, a power to secure legal sanctions when another breaks his promise. 
freedom from contract. ${ }^{53}$ Freedom to contract holds that persons may consent to legally enforceable transfers of their property rights; freedom from contract holds that transfers of property rights should not be imposed upon them without their consent. In other words, freedom to contract permits consensual transfers, whereas freedom from contract requires them. Agamst a backdrop of several property, these two principles regulate the transfers of several property rights. The "manifested consent of the "rights-holder" is, under norinal circumstances, sufficient to transfer a property right; and property rights may not nornally be transferred without the consent of the rightsholder.

Let us now consider in greater detail exactly how the two-part strategy of decentralized jurisdictions and consensual transfers addresses the first-order problem of knowledge.

\section{a. Decentralized Jurisdiction and the First-Order Problem of Knowledge}

The first-order problem of knowledge has two dimensions: human beimgs need (a) to be able to develop and act upon their own personal and local knowledge, while (b) somehow taking mto account the maccessible personal and local knowledge of others. Decentralized jurisdiction is the principal means of coping with the first aspect of the problem.

Id. at 495. For a discussion of how this characterization of contractual freedom has led Macneil to neglect seriously the crucial function of freedom from contract, see Barnett, supra note 7.

53 See Richard E. Speidel, The New Spirit of Contract, 2 J.L. \& Com. 193 (1982):

In fact, the spirit of a people at any given time may be measured by the opportunity and incentive to exercise "freedom to" and the felt necessity to assert "freedom from." Similarly, the nature of a society and its legal order may be determined by the force and permissible scope of these two concepts of liberty and how the inevitable tension between them is resolved.

Id. at 194. For a discussion of Speidel, see infra notes 118-29 and accompanying text. Some commentators have resisted the term "freedom from contract" on the ground that an obligation imposed without one's consent is not properly called "contractual." By this view, a better term would be "freedom from obligation." Althougl I am obviously sympathetic to equating semantically the term "contract" with consensual obligation, there is a virtue in adopting a more neutral version of the word in order to commumicate with those who are syinpathetic to the "death of contract" movement that equates contractual obligation with that imposed by tort. The term "freedom from contract" rhetorically highlights the injustice of imposing socalled "contracts" on persons without their consent. 
Before explaining further, however, an important caveat is in order. I do not contend that the following abstract principles of decentralized jurisdiction can be used to determine specific allocations of rights to particular individuals. ${ }^{54}$ Instead, these principles serve as functional criteria for evaluating the conventional rules that are needed to make specific allocations. In other words, these general principles cannot take the place of laws to govern the specific allocation of resources, but any such laws should be critically assessed to determine if they function consistently with these principles.

With this caveat in mind, we can characterize a strategy of decentralized jurisdiction by four desiderata. (1) Jurisdiction or discretionary control over resources must be delegated to identifiable individuals and groups. If decisions concerining resource use are to be knowledgeable, decision-inaking authority concerning resource use must belong to the persons and associations with access to such knowledge. Conversely, those who lack the requisite knowledge of resource use should lack the authority to interfere with the decisions made by those with knowledge-at least as a general matter. All else being equal, the distribution of jurisdiction over physical resources should mirror as closely as possible the distribution of access to knowledge in society. Once again, I am speaking now of the types of jurisdiction that a legal system should acknowledge, not any specific allocation of jurisdiction.

(2) The allocation of jurisdiction should reflect an assessment of who is in the best position to have personal and local knowledge of the resources in question. Insuperable knowledge probleins prevent us from allocating jurisdiction on the basis of which particular person or group of persons is actually in the best position to know how certain resources may be used. If a centrahzed institution charged with allocating jurisdictions knew what it needed to know to make such allocations, a decentrahized jurisdictional strategy would be unnecessary. The most we can hope for is to determine the general characteristics of those who are in the best position to have knowledge of potential

\footnotetext{
54 Because this Article necessarily omits consideration of the principles governing the initial allocation of entitlements-in particular, the principle of first possession-some will assume wrongly that I favor initially allocating jurisdictions or entitlements according to some criteria of knowledge or competence. As I explain elsewhere, however, the principle of first possession functions much like the principle of consent to address the problems of knowledge and interest without directly comparing the knowledge or interests of prospective claimants. See Barnett, Function of Property, supra note 3, at 81-84, 91.
} 
resource uses, regardless of whether they in fact always have the best knowledge. In sum, we rely on these general characteristics to estabhish a presumption of competence in favor of individuals and groups who have access to the personal and local knowledge pertaining to their own situation.

To avoid any confusion, I again wish to emphasize what I ain not claiming. I ain not claiming that each individual jurisdiction should originally be allocated according to some criterion of competence or that changes in jurisdiction should be made in this manner. For exainple, I am not claiming that Ann should be given jurisdiction over a berry patch instead of Ben because we independently determine that Ann either knows better or is in a better position to know how the berry patch should be used. This sort of evaluation of the relative competence of particular persons and groups would be nearly as difficult as the substantive decisions that are part of the first-order problem of knowledge. Rather, I am asserting that this desideratum argues in favor of allocating jurisdiction at the level of individuals and associations who as a general matter have access to this information, rather than at the level of more global, overarching institutions that lack access to the relevant knowledge. I have as yet said nothing about how jurisdiction should be allocated among competitors for resources each of whom are on the appropriate level.

(3) The domain accorded any particular individual or group must be bounded. If the distribution of jurisdiction over physical resources mirrors as closely as possible the distribution of knowledge in society, then this also means that such jurisdiction must be limited or bounded. Because access to personal and local knowledge is limited, no one has access to all such knowledge. Consequently, to take the extreme case, no person or group should have jurisdiction over all physical resources.

(4) Because the knowledge of individuals and associations is dynamic, not static, jurisdictional boundaries must be subject to revision. Jurisdiction cannot be allocated once and for all. Knowledge of how resources may be used is constantly changing. Absent the need to contmually adjust the jurisdiction of individuals and associations, we might imagine a centralized regime being able to allocate jurisdiction once and for all. A centralized regime, however, would be overwhelmed by the need to constantly readjust jurisdictional boundaries according to shifting personal and local knowledge. The restricted 
access to such knowledge renders such an approach not merely impossible, but inconceivable.

Although the dynamic nature of the first-order problem of knowledge makes changes im jurisdiction necessary, allowing jurisdictional boundaries to change gives rise to a very ticklish knowledge problem. If a potential user were permitted to displace the present user simply on the basis of a mere assertion that he has knowledge of how resources may "best" be used, this would provide no way of assuring that the prospective user is really im any better position to use the resources than the present user. Interpersonal comparisons of knowledge (or interests ${ }^{55}$ ) cannot rehiably be made by the parties themselves or by third parties. ${ }^{56}$ What is crucial to understand is that some systelmic means of transferring jurisdiction must exist that reflects the knowledge (and interests) of both parties. As I explain in the next Section, contractual consent performs this vital function.

\section{b. How Consent Addresses the First-Order Problem of Knowledge}

Recall the two dimensions or aspects of the first-order problem of knowledge discussed above: (1) one must be able to act on the basis of one's own personal knowledge or the local knowledge one has access to as a member of an association; (2) when so acting, one must somehow take into account the knowledge of others of which each person is hopelessly ignorant. The concept of consensual transfers addresses both dimensions of the first-order problem of knowledge. First, permitting consensual transfers of jurisdiction enables persons to act on the basis of their personal and local knowledge by authorizing them to exchange jurisdictions they currently have for jurisdictions they believe they can put to better use. In this way, a transfer of a person's jurisdiction refiects her local and personal knowledge.

ss The first-order problem of knowledge cannot be entirely divorced from interests if for no other reason than because one of the things that persons and associations have knowledge of is their interests.

56 This explanation differs somewhat froun the account given in Barnett, Function of Property, supra note 3, from which this Section is drawn. There, I appear to suggest that the fact of changing knowledge creates a problem of deciding which of two claimants has the best or superior knowledge of how resources may be used. I wish to stress here, however, that I do not think that this sort of systemic interpersonal coinparisons of knowledge (or interests) is possible. The problem of changing knowledge simply exaccrbates the problem of enabling (and forcing) persons to take the knowledge of others "into account" when they decide how resources may best be used. 
Second, requiring that all transfers of jurisdiction be by consent addresses the second dimension of this knowledge problem by enabling -indeed forcing ${ }^{57}$ - persons to take into account the knowledge of others when making their decisions. For changes in boundaries to reflect the knowledge of all affected parties, such revisions must be based on the manifested consent of the individuals or associations whose boundaries are changed. By requiring consent, the new claimant is coinpelled to take the knowledge of the present "jurisdictionholder" into account-including the present holder's knowledge of her own perceptions, preferences, opportuinties, etc.

For example, if Ann, based on her knowledge of her situation, would prefer to inamtain jurisdiction than see it transferred to Ben, then to obtain Ann's consent to a transfer, Ben must offer Ann soinething he thinks she would value more. In other words, the onus falls upon Ben to provide Ann with jurisdiction over some other resource that she could put to better use than the jurisdiction she currently holds. So, for example, Ben could offer Ann jurisdiction over a book she has yet to read in exchange for her jurisdiction over a book she has already read. Only if Ben must obtain Ann's consent is there any assurance that his claim to jurisdiction will take her knowledge into account.

But the requirement of consensual transfers affects our ability to take into account the knowledge of others far more profoundly than this simple "micro" example suggests. Such a requirement also makes possible the evolution of a powerful "macro" institution that enables personal and local knowledge to be "encoded" and transmitted worldwide in a form that can be easily understood by others and mcorporated into their decisions without centrahzed direction. In short, the requirement of consent permits the evolution of a set of resource prices.

57 The fact that a person must take the knowledge of others into account addresses, not the problem of knowledge, but a pervasive problem of interest discussed below: the partiality problem. See infra text accompanying notes 65-69. The set of resource prices that results from this requirement, however, does address the second aspect of the first-order problem of knowledge by enabling persons to take the knowledge of others into account when they decide whether and how to act. In this respect, the ability of the consent requirement to address the knowledge problem depends to some extent on its ability also to address the pervasive problein of interest that I am calling the partiality problein. 
Prices are by far the most neglected form of knowledge we have. ${ }^{58}$ The reason for this is that the knowledge embedded in prices is not explicit; we are never conscious of it as knowledge. It is encoded knowledge, and we are conscious only of the code. Prices reflect the vast personal and local knowledge of the many competing uses to which any physical resource may be put. My coinputer is constructed of plastic, glass, various metals, and other resources. My desk is made of wood. These resources could have been used in a variety of other ways by people throughout the globe. I have not the shightest way of knowing even a small fraction of the specific alternative uses that others might find for these resources. And yet without a comprehensive knowledge of all the alternative uses of these resources, how can a knowledgeable decision be made on how these resources should be used?

I have already explained how, $\mathrm{m}$ light of the dispersed nature of personal and local knowledge, the problem of knowing alternative uses of resources is immense. It would require the compilation of all persons' personal knowledge of perceptions, interests, and opportunities and all local knowledge of associations as to their shared interests and opportunities, the integration of this knowledge into a coherent plan, and the communication of everyone's allocated role. This is a knowledge problem of such enormous proportions that less information is preferable to more. That is, even if we could have direct access to all the knowledge we require, the sheer voluine of such knowledge would prevent us from putting it to use. We need somehow to condense this knowledge into a usable form. We need to convert it to a form of local knowledge that can itself be nitegrated into each person's personal knowledge. And this process of condensation need not be perfect to be superior to the only alternative: near-total ignorance that results from the general niaccessibility of personal and local knowledge. This vital function is performed by the device of resource prices.

Resource prices condense the personal and local knowledge of each one of us into a form of local knowledge that can be nitegrated into the personal knowledge of all of us. Resource prices are local knowledge nisofar as they are comniunicated from one person to another in

58 Although some economic literature stresses the importance of prices, the knowledgedisseminating function of prices is largely unknown-or, if known, then widely ignored-in political and legal theory dealing with the importance of property and contract. 
an intelligible form. Once communicated, they may be integrated into the personal knowledge of individuals concerning their available opportunities. For example, a trip to Aix-en-Provence has a resource price attached to it. When I consider this choice, I must consider the subjective cost to ine of paying this price. This cost is the inost highly valued set of opportunities that I will forgo by choosing to go to Aix. ${ }^{59}$ Less formally, I must consider what I will have to sacrifice to make the trip. Of course, even with a market price of zero, there is no such thing as a truly cost-free trip to Aix, because such a trip will require nie to forgo other potential uses of my time. But the inonetary price to travel to Aix will strongly influence the cost to me of such a trip. And the monetary price reflects the uses to which others may put the resources that it would take to get me to Aix. ${ }^{60}$

Prices are able to communicate this information, however, only because the consent of those with jurisdiction over particular resources is required before jurisdiction may be transferred to another. None of this calculation would have been performed had I not been required to obtam the airline's consent to fly me to France and had the airline not been required to obtain the consent of all those whose cooperation is needed to make the flight possible. The need of others to obtam the consent of a jurisdiction-holder neans that anyone wishing to obtain a transfer of jurisdiction niust offer the present jurisdiction-holder jurisdiction over other resources that the present holder believes he or she would put to better use. The types of offers, as well as the number of persons offering to make exchanges, educate the holder of the value that others place on the resources. When this

59 For a discussion of the subjective costs of choice, see James Buchanan, Cost and Choice (1969).

60 I do not consider here how the medium of exchange that also is needed for a price system to operate is chosen. Historically, the most popular and useful media of exchange-gold and silver-have evolved from the countless consensual choices of consumers. The evolution of money from consensual exchange has long been recognized:

[I] $f$ he would give his Nuts for a piece of Metal, pleased with its colour; or exchange his Sheep for Shells, or Wool for a sparkling Pebble or a Diamond, and keep those by him all his Life, he invaded not the Right of others, he might heap up as much of these durable things as he pleased; the exceeding of the bounds of his just Property not lying in the largeness of his Possession, but the perishing of any thing uselesly [sic] in it.

And thus came in the use of Money, some lasting thing that Men might keep without spoiling, and that by mutual consent Men would take in exchange for the truly useful, but perishable Supports of Life.

John Locke, Two Treatises of Government 318-19 (Peter Laslett ed., 2d ed. 1967) (3d ed. 1698) (fourth emphasis added). 
value reaches a certain level, the holder is induced to inake an exchange, thereby revealing that the value she placed on the resource was less than the value to her of the resources offered. Without the requirement of consent, this information would never be revealed and meaningful prices could not arise.

With a set of resource prices, a person is able to-indeed nuust ${ }^{61}$ decide whether to use a resource, save it for later use, or exchange it for another resource by comparing her knowledge of the different uses she has with the knowledge and preferences of countless others that are encoded in the market price for the good. If the market price is higher than the value she places on the resource then she will be induced to exchange it. If the market price is lower, she will either use the resource or conserve it for later use or exchange.

The process is dynamic in that the holder of jurisdiction is incorporating price signals - a form of local knowledge-into the personal knowledge on which she bases her decision. In turn, her decision (to hold or sell) will influence the price signals received by others and will then be incorporated into their personal knowledge. For example, my ongoimg decision not to sell niy house both influences the market price of housing and, simultaneously, is influenced by the market price of my house and by the market price of alternative housing. True, the effect of niy decision alone is unlikely to "move the niarket," but, in the aggregate, the current niarket price is a product of everyone's decision either to sell or not to sell. This process of knowledge generation and transmittal could not occur if the rights to resources could be transferred without the consent of the rights-holder.

\section{c. Summary}

The concepts of several property and freedon of contract both help address the first-order problem of knowledge. By delegating discretion to make choices concerning the uses of resources, several property enables persons and associations to act on the basis of their personal and local knowledge without outside interference. Freedon to contract enables persons to exchange their rights on the basis of their knowledge that other rights would better serve their purposes.

61 Once again, by forcing - as opposed to enabling-persons to take into account the knowledge of others, the requirement of consent also addresses the partiality problem discussed infra text accompanying notes 65-69. 
It also enables them to make gifts of their rights on the basis of their knowledge that others could make better use of these rights. Freedom from contract protects the expectations of current rights-holders, permitting them to put their knowledge into effect over a period of time free from the interference of others.

Moreover, without adherence to the principle of freedom from contract, resource prices would not arise. In making our personal or local decisions about resource use, each person or association needs "imput" or knowledge about the potential resource use of others relative to the supply of resources. Resource prices provide this knowledge in a usable forin and in the ouly manner that such knowledge could ever be provided systermically. Such a knowledge-conveying mechanism would cease to exist without the requirement that one's jurisdiction over resources cannot be displaced without one's consent. Nonconsensual transfers of rights "short-circuit" the price system of knowledge transmittal and make it impossible for individuals and associations to take the knowledge of others into acconnt when putting their own knowledge into action.

\section{B. Two Problems of Interest ${ }^{62}$}

The fact that I have so extensively discussed how consent addresses the first-order problem of knowledge might suggest that I view this as its only important social function. To the contrary, even if there were no knowledge problein, we would still face a serious social problem of interest. The ability of the hiberal conception of justice, with its principle of freedom of contract, to handle this pervasive problem provides an mdependent and reinforcing reason for adhering to the requirement of consensual transfers. ${ }^{63}$

The problems of interest take many forms, but they all spring from the common tendency of persons to make judgments or choose actions that they behieve will serve their subjective preferences (although these preferences may not always be self-regarding). This tendency is not, by itself, a problem. Acting out of interest can be considered a problem only aganist some norinative background that

62 This Section is adapted, with some substantive revisions, from the relevant portions of Barnett, Function of Property, supra note 3.

63 For a discnssion of how parallel, reinforcing methods of analysis provide confidence in the conclusions reached by any one valid method of analysis, see Barnett, Virtues of Redundancy, supra note 32 . 
distinguishes objectionable from unobjectionable actions. In this Section, I consider two distinct problems of interest: the partiality problem and the incentive problem. ${ }^{64}$ These problems of interest would require some solution even if we faced no problems of knowledge. Those who urge that contractual consent be abandoned or highly qualified must explam how these problems can be handled success-

- fully in some other inanner.

\section{The Partiality Problem}

The partiality problem arises from the fact that people tend to make judgments that are partial to their own interests or the interests of those who are close to them at the expense of others. The word "partial" reflects both the cause and consequence of this problem. One meaning of the term is "affecting ouly a part; not complete or total." 65 In this sense, it is inevitable that individuals can have only a partial or incomplete view of the facts that go into reaching any decision. It is very hard to avoid seeing the world from one's own particular, and therefore partial, vantage point. Like other interested action, the existence of partial judgment is not itself a problem. The term "partial" merely denotes an incomplete, rather than an incorrect point of view.

But this partiality or incompleteness of vision also leads to the other meaning of the term partial: "favoring one person, faction, etc. more than another; biased; prejudiced." 66 Partiality, $\mathrm{m}$ this sense, is judgment affected by interest. Once again, this is not im itself a problem. Just as most of our actions are motivated by interest, much of our judgment is to some degree partial towards our own interests and the interests of those whom we care about.

A partiality problem arises when persons whose viewpoints are influenced by their own interests are called upon to make judgments

64 A third important problem of interest-the compliance problem-involves gaps that may arise between the requirements of justice and the rule of law and a person's perception of interest. In most circumstances, this gap is narrowed by powerful socializing influences. In others, it is narrowed by the use of force or power. The use of force or power results in two serious problems of power: the problem of enforcement abuse and the problem of enforcement error. The liberal conception of justice and the rule of law-including the concepts of several property and freedom of contract-addresses these problems as well as those discussed in the text, but space prevents me from examining them here.

65 Webster's New Twentieth Century Dictionary 1306 (2d ed. 1978).

66 Id. 
that are supposed to take imto account the interests of persons remote to them. This type of impartial or objective assessment is required when systems of resource allocation require some person or persons to make a general or society-wide determination of how resources are to be used. Yet it is simply very difficult for persons charged with making such a decision to set their own interests in proper perspective im order to make an impartial assessment. In sum, the partiality problem refers to the difficulty of making judgments concerning resource use that take into account all available personal and local knowledge without succumbing to the tendency of persons to give priority to their own knowledge and interests.

Even if, contrary to my thesis (but as inany beheve), persons with centralized jurisdiction over resources could gain sufficient access to the personal and local knowledge of others to address the knowledge problem, we would still need to confront the problem of partiality. Assuming that these persons have access to the local and personal knowledge of others, what assurance do we have that their decisions concerning resource use will be based impartially on this knowledge, rather than on a partial judgment of what is in their own imterest? ${ }^{67}$ Although several property plays an important role im addressimg the partiality problem, ${ }^{68}$ I shall confine myself here to explaining how this problem is addressed by the principles of freedom of contract.

67 Within the public clioice school of economics, "interest group theory" argues that mucli of the behavior of government actors can be explained as exercises of interest rather than as exercises of inpartial judgment of the public good. For a sympathetic portrayal of this approacl, see, e.g., Iain McLean, Public Choice (1987); Jerry L. Mashaw, The Economics of Politics and the Understanding of Public Law, 65 Chi.-Kent L. Rev. 123 (1989). For a critical appraisal, see Daniel A. Farber, Democracy and Disgust: Reflections on Public Clroice, 65 Chi.-Kent L. Rev. 161 (1989).

68 See Barnett, Function of Property, supra note 3. In sum, in a regime of several property, the jurisdiction over resources becomes radically dispersed. Consequently, partial judgment can have a inuch inore himited impact tlian in a system where one person or group exercising partial judgment has ultimate jurisdiction over all resources. In this way, several property leads to the coinpartınentalization of partiality. In addition, this compartmentalization inakes possible a system of cliecks and balances on the exercise of partiality since each jurisdictionholder has a limited power to retaliate when adversely affected by another person's exercise of partial judgment. Such a situation has been slown to be conducive to the evolution of a cooperative regime of reciprocity. See Robert Axelrod, The Evolution of Cooperation (1984); Robert C. Ellickson, Order Without Law: How Neighbors Settle Disputes (1991); Robert Sugden, The Economics of Rights, Co-operation and Welfare (1986).

The liberal conception of justice is, therefore, far more modest in its conception of several property than the socialist conception of public property which does allow for the de facto, if not de jure, ownership of large segments of the resources in a society-perlaps every 
Even if a prospective rights-holder had rehable access to the knowledge of a current rights-holder, when seeking to obtain the rights held by another, we cannot expect the prospective rights-holder to be impartial in assessing whether he can make better use of the resources than the present rights-holder. By making consent of a rights-holder a necessary condition of rights transfers, the principle of freedom from contract forces prospective rights-holders to take the knowledge of current holders into account when deciding whether to effectuate a transfer.

The fact that property rights may not transfer without the consent of the current owner means that, to acquire the right to use these resources, any prospective owner is compelled to induce the current rights-holder to consent to a transfer. The amount and kind of this inducement reflects the personal and local knowledge of the current rights-holder as to how these resources may be used. By becoming part of the prospective owner's cost of obtaining control over the resource in this manner, the knowledge of the current rights-holder is brought to bear on the allocational decision. A prospective owner is compelled to take the current rights-holder's knowledge into account without requiring that the prospective owner have direct access to the personal or local knowledge of the current rights-holder. ${ }^{69}$

It is now apparent how the system of resource prices that arises from adhering to the principle of freedom from contract addresses not only the first-order problem of knowledge but also the partiality problein. The requirement that everyone pay the price for resources held by others does more than enable persons to take into account the knowledge of others. It also forces them to take the knowledge and interests of others into account, even when they would not otherwise find it in their interest to do so. In this manner, the concept of freedom of contract functions with the concept of several property to amehorate the partiality problem.

resource-by a comparatively small number of persons relative to the society as a whole. This is "propertarianism" with a vengeance.

69 In property theory, the principle of first possession also performs this function with respect to subsequent claimants of previously unowned property that has been subject to the control of a first possessor. See Barnett, Function of Property, supra note 3, at 81-84. 


\section{The Incentive Problem}

Solving the first-order problein of knowledge by adhering to the concept of several property assumes that people will have sufficient interest to actually use their access to knowledge of how resources may be used. It assumes that the prospective benefits of acquiring knowledge and putting it to use will outweigh the subjective costs of such action. Suppose, however, that rights-holders lack adequate incentives to use their access to knowledge when deciding how to use their resources. This incentive problein concerns choices among actions that justice permits. It refers to the need to close the gap between the conduct that the decentralized allocation of resources permits, and what persons subjectively perceive to be in their interest to do. $^{70}$

The incentive problein arises most graphically when the benefits of exercising knowledgeable control over resources do not accrue to the person or persons exercising such control. To appreciate the nature of the incentive problein, let us imagine a world of several property where control over resources was decentralized in much the same manner as in western countries. Those generally in the best position to have beneficial knowledge of resource use would be those who had legal control as well. In other words, the allocation of legal control to individuals and associations would closely reflect the distribution of personal and local knowledge.

Now imagine that all the benefits accruing froin a knowledgeable exercise of control were routinely siphoned off and given to othersfor example, via a steeply progressive income tax or a confiscatory wealth tax. The mability to reap the benefits from using one's knowledge to control resources would greatly reduce the incentive to exercise knowledgeable control in the future. Some incentive to act productively might still exist if exercising control were for some reason intrinsically rewarding or if one had a special affinity for the person receiving the benefits. As the inherent interest in doing a job declines or as the recipient of the benefits becomes increasingly reinoved, however, even this residual incentive to act knowledgeably would dechine.

\footnotetext{
70 In contrast, the compliance problem, see supra note 64 , is the problem of interest that arises when a gap exists between the condnct that the decentralized allocation of resources requires, and what persons perceive to be in their interest to do.
} 
This analysis suggests that, just as the distribution of control over resources should correspond to the distribution of knowledge in society, the distribution of benefits should closely correspond to the distribution of control. Although the concept of several property disperses the control of resources throughout society in a way that tends to match the distribution of knowledge, an inportant function of the two principles of freedom of contract is to address the incentive problem.

The principle of freedom from contract ensures that changes in control of resources reflect the knowledge of the original rightsholder. Only if the rights-holder consents to a transfer will it be recognized as valid. Consent will not be given uuless the rights-holder subjectively values the distribution of rights resulting from the transfer inore highly than the original distribution of rights. Without a requirement of consent, the incentive to use one's knowledge to improve the property within one's rightful jurisdiction would be undercut by the prospect that others could dispossess the rightsholder without his or her consent.

The principle of freedom to contract provides incentives for beneficial transactions by enforcing agreements motivated by the prospect of receiving a benefit or "profit." This prospect creates powerful incentives to investigate and discover previously unknown opportunities for beneficial transfers. ${ }^{71}$ Entrepreneurship is the abihity to identify previously unknown or neglected opportunities for beneficial transactions. ${ }^{72}$ If contracts producing so-called "speculative" gains were unenforceable, then the incentive for such entrepreneurial activity would be eliminated.

Conversely, the prospect of incurring a "loss" induces a level of caution in persons' actions. One has an incentive to be careful about putting one's knowledge into action if one incurs the full cost of any mistake. Moreover, the only way to eliminate losses is to transfer

71 I am making no claim concerning "optimal" incentives for entrepreneurship or other productive activity. I am skeptical that employing explicit optimization analysis can in practice improve upon the incentives provided by a legal system whose specific rules are consistent with the liberal principles of several property and freedoin of contract. Even if such improvement were possible, however, this sort of analysis would justify ouly comparatively slight deviations from the baseline of entitlements established by these hiberal principles.

72 The theorist inost responsible for stressing the nature and importance of profits and entrepreneurship is Israel Kirzner. See, e.g., Israel M. Kirzner, Competition and Entrepreneurship (1973). 
resources to the actor who has made the bad bargain from others who have not. In the absence of consent by the person to whom the loss is shifted-for exainple, a consent to a risk-pooling or insurance scheme-such a policy of coerced loss spreading will have adverse mcentive effects on those froin wliom this compensation is confiscated.

Freedom of contract, then, botli inhibits transfers adversely affecting interest and encourages beneficial transfers. The principle of freedoin from contract-that is, no transfers without consent-ensures that rights transfers will not create negative incentives. The principle of freedom to contract-that is, consensual transfers are validmakes entrepreneurship possible by ensuring that positive imcentives exist for beneficial riglits transfers. ${ }^{73}$ In these ways, freedom of contract addresses the problems of interest as well as the first-order problein of knowledge.

\section{Communicating Justice: The Second-Order Problem of Knowledge}

In the functional analysis just presented, the consent that addresses the problems of knowledge and interest is subjective-what soine view as the only "real" assent. ${ }^{74}$ But rehance on subjective assent encounters the following difficnlty: because every person's intentions are part of his or her personal knowledge, and because these intentions are inaccessible to observers, they provide an extremely probleınatic basis for determining rights transfers. Lacking any direct access to these imtentions, recipients of transfers can never be entirely sure ex ante that subjective assent is present. Third parties seeking to adjudicate conflicting claims of rights also have difficulty inaking such an assessment ex post.

More generally, even if a consensus existed that adhering to the hiberal conception of justice was the best way to address the first-order problein of knowledge, this strategy would fail if no one in the world

73 Once again, as elsewhere in this analysis, I am not claiming that freedom of contract performs these functions either perfectly or optimally. I ain assuming, however, without showing, that freedoin of contract performs thein better than any practical alternative; well enough, in fact, to place the burden on anyone who would undermine this primciple (for whatever reason) to explain how the problems it handles can be handled satisfactorily in soine other manner.

74 See infra Part IV. 
had access to its requirements. Without this knowledge no one's conduct could be influenced by the dictates of justice, an order of actions would not be achieved, and the first-order problem of knowledge would go unaddressed. Unless acting consistently with precepts of justice is entirely instinctive to human beings, we need a way to disseminate knowledge of justice im such a inanner as to make its requirements accessible to everyone in a society.

The second-order problem of knowledge, then, is the need to communicate knowledge of justice in a manner that makes the actions it requires generally accessible to all. It is "second-order" because it arises only once the hiberal conception of justice is used to address the first-order problem of knowledge.

\section{The Second-Order Problem of Knowledge and the Rule of Law}

The problein of commumicating the requirements of justice is handled by the formal requirements of legahty associated with the liberal conception of the rule of law. A well-known summary of these elements of legahity was provided by Lon Fuller:

[T] he attempt to create and maintain a system of legal rules may miscarry $\mathrm{m}$ at least eight ways; there are in this enterprise, if you will, eight distinct routes to disaster. The first and most obvious hies in a failure to achieve rules at all, so that every issue must be decided on an ad hoc basis. The other routes are: (2) a failure to publicize, or at least to make available to the affected party, the rules he is expected to observe; (3) the abuse of retroactive legislation, which not only cannot itself guide action, but undercuts the integrity of rules prospective in effect, since it puts them under the threat of retrospective change; (4) a failure to make rules understandable; (5) the enactment of contradictory rules or (6) rules that require conduct beyond the powers of the affected party; (7) introducing such frequent changes in the rules that the subject cannot orient his actions by them; and, finally, (8) a failure of congruence between the rules as announced and their actual administration. ${ }^{75}$

Each of these desiderata-as Fuller called them-can be understood as formal requirements of "legality" that inake it possible to handle the second-order problein of knowledge. Actions by a legal system conforming to these formal characteristics convey the substance of just conduct to persons deciding how to act.

75 Lon L. Fuller, The Morality of Law 38-39 (rev. ed. 1969). 
In sum, to achieve a relational order of actions, it is not enough that we have an appropriate conception of justice. It is also necessary that our principles of justice be cast into a usable form. ${ }^{76}$ Although much more can and should be said about the liberal conception of the rule of law, ${ }^{77}$ my purpose here is simply to facilitate a better understandimg of the functional relationship between subjective and objective consent in contract.

\section{From Subjective to Objective Consent}

The fornal requirement of the rule of law that is needed to address the second-order problem of knowledge suggests that an assent to alienate rights must be manifested in some inanner by one party to the other to provide a discernible criterion of effective transfer. Without a inanifestation of assent that is accessible to all affected parties, the system of bounded individual discretion that concepts of justice seek to define will fail to achieve its principal function. At the time of a transaction, it will have failed to identify clearly and communicate to both parties, and to third parties mcludimg adjudicators, the rightful boundaries that must be respected. Without such communication, parties to a transaction, and third parties, cannot accurately ascertain what constitutes rightful conduct and what constitutes a commitment on which they can justifiably rely. Disputes that might otherwise have been avoided by a better precept will occur, and the attendant uncertainties of the transfer process will undermine the ability of the parties to rely on their knowledge of just domains.

There is, im sum, a need to be able to "rely on the appearances" with respect to rightful domains. Only a general reliance on objectively ascertainable assertive conduct will enable a decentralized system of rights to perform its allotted boundary-defining function. In

\footnotetext{
76 See Ellickson, supra note 68, at 48 ("'R]ules cannot have instrumental effects uuless they are communicated to the relevant actors."). While the second-order problem of knowledge concerns the need for formal rules and principles that are capable of guiding conduct, the third-order problem of knowledge, not discussed here, concerns how we settle on a specific set or sets of conventional rules and principles when more than one set of conventions can address satisfactorily the second-order problem of knowledge. In my view, certain features of the rule of law associated in Anglo-American legal systems with the process of common-law adjudication comprise part of the liberal solution to this problem.

77 See, e.g., Symposium on Law and Philosophy, 14 Harv. J.L. \& Pub. Pol'y 615 (1991); Barnett, Justice \& the Rule of Law, supra note 3.
} 
contract theory this is known as the "objective theory of assent."78 We hold persons to the "reasonable" or normal meaning that their conduct conveys to others. ${ }^{79}$ For example, signing a written contract conveys the message, "I am transferring some of my rights to the other party." The imputation of meaning to conduct requires reference to a conventional system of language that is shared by the relevant community. So, for example, "yes" means yes, and "no" means no within the community of Enghish-speaking people. Asking what "yes" means to a reasonable person is to ask what meaning a normal participant in the English-speaking community would attach to this sound, given the context im which it was uttered. A person who did not speak English would be unable to express an opinion, however "reasonable" this person imight otherwise be. The objective approach acknowledges the conventional nature of language and otlier modes of communication. Within contract law, it provides a way of handling the second-order problem of knowledge. Contracts based on mainfested consent, then, operate similarly to resource prices by converting the personal knowledge of each party into a form of local knowledge that is accessible to both parties.

Understanding the function that an objective approach to justice plays im addressing the second-order problem of knowledge also enables us to appreciate the hinits of this approach. For example, the second-order problem of knowledge would be solved (botli ex ante and ex post) if it could be slown that one party to a contract actually knew or had access to the fact that the other party attached an idiosyncratic meaning to a linguistic utterance that would normally mean something quite different. In this case, the purpose for which we adopt the objective approach - to enable persons to rely on the appearances created by otliers because subjective intentions are generally inaccessible-is satisfied by actual knowledge that the appearances in this case are deceiving. Therefore, in contract law, we protect a party's reliance on objective appearances, uuless it can be

78 See Farnsworth, supra note $26, \S 3.6-9$, at $118-35$.

79 See, e.g., Restatement (Second) of Contracts § 202(3) (1979) ("Unless a different intention is manifested . . . (a) where language has a generally prevailing meaning, it is interpreted in accordance with that ineaning."). 
shown that the parties shared a common subjective understanding of a term. ${ }^{80}$

With this account of how the liberal conception of the rule of law addresses the second-order problem of knowledge, together with the earher treatment of how consent handles the first-order problem of knowledge and the problems of interest, we can now analyze the functional relationship between default rules and consent. In Part II, I discuss the role of consent in justifying enforcement of default rules, and, in Part III, I explain how consent should influence the choice of default rules.

\section{The Relevance of Consent to the Enforcement of Default Rules}

In inaking a legally enforceable agreement, parties do not only consent to the exphicit terms in their agreement. To enter the "realm" of contract (and leave the "realm" of mere promise), the parties must somehow signal or commuincate their intention to transfer their entitlements or rights to another. ${ }^{81}$ The reasons for requiring consent were elaborated in Part I. By permitting consensual transfers of rights (freedom to contract), we enable persons to adjust resource holdings in accordance with changing knowledge about how these resources may best be used. By requiring consent before resource holdings may rightfully be transferred (freedom from contract), we enable a price mechanism to disseminate a plethora of information concerning the personal and local knowledge of countless persons and associations as to how resources may be used.

Moreover, only by requiring consent can we address two problems of interest I termed the partiality problem and the incentive problem. Freedom from contract addresses the partiality problem by compelling persons to take into account the knowledge of current rights-

80 See Farnsworth, supra note $26, \S 7.9$, at 505 ("In the rare cases of a common meaning shared by both parties, the subjectivists have had the better of the argument."); Restatement (Second) of Contracts $\S 201$ (1) (1979) ("Where the parties have attached the same meaning to a promise or agreement or a term thereof, it is imterpreted in accordance with that meaning.").

81 I postpone for now the important issue of how manifested consent is related to subjective assent. Suffice it to say that, for me, a manifested consent can be "real" even when it is not accompanied by subjective assent. This is because the concept of consent that is at the root of contract theory is communicated consent, though one rcason for the centrality of communicated consent is its close empirieal correspondence with subjective assent. See infra Part IV. 
holders before deciding whether to seek to transfer resources. Freedoin froin contract also addresses the incentive problem by enabling persons to rely upon the existing distribution of resources when deciding whether to einploy their knowledge as to how these resources inay be used and to profit from the benefits that may accrue as a result of their entrepreneurial activity. Without requiring consent to be legally bound before enforcing a transfer of entitleinents, ${ }^{82}$ these social ends will not be attained. To the extent that these purposes or ends are normatively compelling, the requirement of contractual consent is normatively warranted as well. ${ }^{83}$

With this account of the social functions of contractual consent in hand, let us now consider the appropriate role of consent in contract theory. In this Part, I explain three ways in which the inanifestation of consent is significant im any theory that einphasizes the role of default rules in filling gaps im contracts. First, as a conceptual matter, we cannot speak of filling gaps in contracts without some prior ascertainment that a contract exists (with gaps to fill). Consent to be legally bound provides this criterion of contractual obligation and is a necessary element of contractual obligation. Second, consent to be legally bound necessarily implies consent to the apphication of some set of default (and immutable) rules when a gap in the agreennent arises. Under cettain circumstances, this general consent to be legally bound can even be said to constitute a consent to the enforcement of the particular existing default rules, in which case it is both necessary and sufficient to provide a consensual justification for legal enforcement. ${ }^{84}$ Third, the social function of consent also helps to justify a general preference for default as opposed to immutable rules.

\section{A. Consent to Gap-Filling}

We can speak of gaps in a contract that must be filled by default rules only if a contract can first be shown to exist. According to a consent theory of contract, prima facie contractual obligation arises when a person "voluntarily perform[s] acts that convey[] her inten-

82 Other types of legal obligation, including that defined by tort law, concern different circumstances that can justify transferring entitlements without consent.

83 See supra note 33.

84 When these conditions are lacking and a consent to be legally bound is therefore insufficient to justify enforcement, the desiderata described infra Part III can combime with this general consent to provide sufficient consensual grounds for enforceinent. 
tion to create a legally enforceable obligation by transferring alienable rights." 85 And, as I have explained:

In a system of entitlements where manifested rights transfers are what justify the legal enforcement of agreements, any such manifestation necessarily imphes that one intends to be "legally bound," to adhere to one's commitment. Therefore, the phrase "a manifestation of an intention to be legally bound" neatly captures what a court should seek to find before holding that a contractual obligation has been created. ${ }^{86}$

Moreover, by manifesting tlieir consent to be legally bound, parties necessarily-tliat is, as a conceptual matter-consent to the jurisdiction of some adjudicative and enforcement meclianism. Witliout this added implication, a consent to be legally bound carries no more meaning than any other commitment or promise. ${ }^{87}$ Althougl there need not be consent to a particular enforcement mechanism, consent to be legally bound is what creates the enforceable legal obligation in a pure contracts case-tliat is, a case that arises from the claim that riglits have been transferred by voluntary commitment of the rightsholder. ${ }^{88}$

To make a contract according to this approach, tlien, a party must explicitly or miphicitly manifest assent to be legally bound. Given that all real world contracts are not completely specified, ${ }^{89}$ it follows that a consent to be legally bound entails one of two propositions: (1) when a dispute arises that is not covered by an exphicit term of the contract, whatever court has jurisdiction to resolve tlie dispute loses its jurisdiction and any loss that may liave resulted from the transaction remains where it liappened to fall; or (2) when a dispute arises that is not

85 Barnett, Consent Theory, supra note 27, at 300. While beyond the scope of this article, some of the problems that this refined version of the principle of consent is intended to handle are considered in Barnett, Inalienable Rights, supra note 27.

86 Barnett, Consent Theory, supra note 27, at 304.

87 Cf. Arthur Corbin, Corbin on Contracts $\$ 110$ (1963) ("The mere fact that one man promises something to another creates no legal duty and makes no legal remedy available in case of non-perfornance. To be enforceable, the promise must be accompanied by some other factor."). In contrast with other theories of contract, a consent theory specifies that this "other factor" is the presence of a manifestation of intention to be legally bound.

88 Of course, the fact that consent is necessary for the creation of contractual obligation does not mean that contractual obligation is the only kind of obligation that can arise. For example, to enter the realm of tort, one need not consent to the jurisdiction of some adjudicative and enforcement mechanism.

89 See supra notes $2-3$ and accompanying text. 
covered by an explicit term of the contract, whatever court has jurisdiction to resolve the dispute retains its jurisdiction and may allocate the loss according to some set of primciples. Although each of these propositions is logically consistent with a manifested intention to be legally bound, because the concept of consent is a communicative one, we must always seek the most plausible interpretation of the conduct of the parties within the relevant commumity of discourse. ${ }^{90}$

In my judgment, the second of these propositions inore accurately expresses the actual intentions of most contracting parties when they consent to be legally bound. If so, this will be the conventional or communicated meaning of consent to be legally bound, and it thus becomes the presuinptively applicable, default ineaning of consent. ${ }^{91}$ Deviants froin this norm are free to contract out by specifying that the first proposition apphies to thein. In the absence of such an opt out, when courts enforce these background rules, they do so with actual, not merely hypothetical, consensual authorization. ${ }^{92}$

Therefore, according to a consent theory of contract, default rules fill gaps in contracts to which the parties have manifested an overall consent. Uuless consent was manifested by the parties there can be no contractual gap to fill. Whatever reasons of principle or policy support one default rule over another, or an immutable rule over a default rule, there is always an additional reason that partly explains and justifies the enforcement of whatever background rules are chosen: the parties have manifested their intent to be legally bound. In answer to the question of why enforcement of a particular default rule is justified, there are-to borrow an expression from Richard

90 Of course, if it can be shown that the parties are highly idiosyncratic and have in essence their own "private language," then the "community of discourse" consists solely of them. Normally, however, when gaps arise in an agreenent the relevant coinmunity of discourse is either the general community of which both parties are ineinbers or, where the parties are inerchants, their particular trade.

91 The liberal conception of the rule of law, discussed supra Part I, makes the advanced proinulgation of legal rules a norm of a truly legal systein, so presuinably the individual's (or her lawyer's) choice of legal systein will depend on the pre-existing background rules of that system. Of course, this analysis neglects the endenic problem of changes in old promulgated rules-the traditional jurisprudential problen of ex post facto lawmaking-for the parties to a dispute where an old rule is changed or a new rule is devised. But this possibility is not entirely unexpected. The primciples governing such eventualities can also be known in advance. (At some point the diminishing probabilities at each level of "rule failure" cut short in practice what may in logic be an infinite regress.)

92 But this is not to say that a consent to the enforcenent of background rules would always justify the enforcement of any background rule. See infra Part III. 
Epstein-always at least two "becauses,"93 one of which is that the parties consented to be legally bound. Or-to use a phrase made popular by Richard Wright in the field of tort causation ${ }^{94}$ - both consent and whatever other considerations influence the choice of default rules are "necessary elements of a sufficient set" of justifications for legal enforceinent. 95

Other writers have acknowledged the existence of this "indirect" consent to default rules. For example, although Subha Narasimhan maintains that "[c]ontracting parties are frequently required to perform obligations to which they never really consented,"96 and therefore that contractual duties provided by gap fillers "cannot be justified as consensual,"97 in a footnote she concedes that even when consent to a particular default rule is lacking, "[c]onsent does exist in the broadest sense that the parties have accepted the underlying legal rules governing contracts." Charles Fried, too, argues that "[a] contractual relation ... is, after all, freely chosen. Indeed this is the same idea as that the contractual parties are in a common enterprise-an enterprise they chose to enter." 99

93 Richard A. Epstein, Pleadings and Presumptions, 40 U. Chi. L. Rev. 556, 571 (1973) (when a defendant is provided with necessaries, "[i]t cannot be said simply that the defendant 'is bound, not because he has agreed, but because he has been supplied.' The case has two 'becauses,' the first of which is the agreement to purchase.").

94 See Richard W. Wright, Causation in Tort Law, 73 Cal. L. Rev. 1737, 1788-1803 (1985) (explaining and defending the "NESS test" of causation in tort theory); Richard W. Wright, Causation, Responsibility, Risk, Probability, Naked Statistics, and Proof: Pruning the Bramble Bush by Clarifying the Concepts, 73 Iowa L. Rev. 1001, 1018-42 (1988) (same from a more normative perspective).

95 Perhaps a further analogy to computers will help to illustrate this point. The miraculous word-processing programs that provide us with all sorts of default settings are called application programs. As we all know, however, no application program can run without an operating system such as MS-DOS or UNIX to tell the computer liardware how it is supposed to work. These operating systeins are often referred to as the "shell" in which an application program runs. It is maceurate to say that the default rules of my word-processing program can be explaimed solely by examining the programming of WordPerfect. To fully understand how they work requires us to consider the programming provided by MS-DOS as well. Analogously, the concept of consent as a criterion of contractual obligation provides the shell or operating system that is required before any theory of default rules can be successfully run.

96 Narasimhan, supra note 8 , at 1124 .

97 Id. at 1181.

98 Id. at 1181 n.155 (emphasis added).

99 Fried, supra note 9, at 73. Ian Macneil is another contract theorist who has acknowledged the existence of "consent to legal relations," but his analysis of its theoretical significance is ainbiguous. I examine his treatment of consent at length in Barnett, supra note 7. 
But although Fried embraces the notion of underlying consent to create legal relations in his effort to square court-imposed gap-fillers with his subjectivist, promise-based theory, Narasimhan disputes the theoretical significance of consent. "This type of "consent," she argnes, "does not advance the goals of expectation enforcement."100 Notwithstandimg that Narasimhan places quotation marks around the word consent, she does not actually question the reality of consent to default rules. Instead, by questioning its relationship to "the goals of expectation enforcement" and "the bargain principle," she demes the theoretical significance of this consent.

I suspect that the justificatory relationship between consent and gap-filling is generally overlooked by Narasimhan and others because many who have written about gap-filling employ economic analysis. In standard economic analysis, theorists look for "marginal" considerations that will tip the scales one way or the other. Because consent to be legally bound is taken by them as given, and because it does not appear to determine the choice of default rules, it seems to lose its theoretical importance to anyone concerned ouly with choosing the correct default rule. Yet it is the "inframarginal" existence of consent that, in part, justifies the enforcement of whatever default rule is chosen. The default rule theorist can ignore consent only by assuming away the problem of contractual obligation for which the concept of consent is the answer and upon which any theory of default rules must depend.

\section{B. Consent to the Enforcement of Default Rules}

What I have called a consent theory of contract proposes that a manifested imtention to be legally bound is a necessary element of a prima facie contractual obligation. Unless parties have in some fashion-whether forinally or informally ${ }^{101}$ _manifested an intention to

100 Narasimhan, supra note 8 , at $1181 \mathrm{n} .155$. She also says, "this type of general awareness [that a legal system will impose on a party the risk] of uncertainty falls far short of the intelligent appraisal and allocation of known risk which is necessary to achieve the goals of the bargain principle. Therefore it should not be included in the estimate of party expectations." Id. at 1133 n. 28 .

101 A consent theory requires that evidence exists to support a rebuttable inference that a party has manifested his or her intention to be legally bound. This evidence need not be limited to a showing of bargained-for consideration but can be soine other fornality or even the presence of detrimental reliance. See Barnett, Consent Theory, supra note 27, at 309-17; Barnett \& Becker, supra note 27, at 449-95. In our article, Mary Becker and I made the 
be legally bound, no contractual obligation exists. ${ }^{102}$ Thus, courts and legislatures are justified in filling gaps in agreements if and only if parties liave manifested their imtent to create contractual relations. Moreover, by imvoking tlie system of legal enforcement, one is implicitly accepting that the legal system may be called upon to interpret the agreement and fill any gaps. Silence in the face of this prospect manifests a consent to those gap-filling provisions that one miglit liave clianged by speaking up. In contrast, with promise-based theories requiring only a promise and some accompanying factor (bargainedfor consideration, detrimental reliance, etc.) to justify enforcement, ${ }^{103}$ the inference of consent to background rules is far froin clear. Persons may make serious promises without having any reason to think that enforcement will ensue shonld they change their minds.

Given tlie opportumity to deviate from the defanlt rules, it is unrealistic to depict implied-in-law default rules as being "imposed upon" the parties in the tort-like sense that this phrase lias acquired over the years. Contrary to the received wisdom, only some of the terms that are implied-in-law are imposed upon the parties witlout their consent. Many of the rules in this category are legitimated by the silent consent of the parties in mucli the same way as evidence law recognizes the possibility that silence in the face of an accusation can constitute an admission. ${ }^{104}$ Silence in the face of defanlt rules can

descriptive claim that, contrary to the received wisdom, most courts do not in practice use promissory estoppel to compensate for harms caused by reliance simpliciter, but instead they use the doctrine either (a) to enforce promises where there exists soine indicia of an overall intention to be legally bound other than the formality of a bargain, or (b) to coinpensate for harms caused by negligent promissory misrepresentations. For a recent article largely adopting the first part of our thesis, see Edward Yorio \& Steve Thel, The Promissory Basis of Seetion 90, 101 Yalc L.J. 111, 113 (1991) ("Section 90, like the doctrine of consideration, works to enforce promises that are likely to be serious.... [T] he prospect of definite and substantial rehiance ... also screens for seriously considered promises." (footnote omitted)). The only difference between their approach and ours is that, while Yorio and Thel speak of "serious" promises, we equate "seriousness" with the presence of a inanifested intention to be legally bound.

102 The social function of requiring a manifestation of assent will be discussed infra Part IV. 103 Sec Restatement (Second) of Contracts $\S \S 17,71$ (1979).

104 As one evidence authority explains: "If a statement is made by another person in the presence of a party to the action, containing assertions of facts which, if untrue, the party would under all the circumstances naturally be expected to deny, his failure to speak has traditionally been receivable against him as an admission." McCormick on Evidence § 270, at 799 (Edward W. Cleary ed., 3d ed. 1984). 
constitute an "indirect" consent to courts using these default rules to supply terms when a gap exists in the parties' expression of consent.

An important caveat is needed here, however. Although a inanifested consent to be legally bound constitutes a general consent to the enforcement of some set of default rules, the parties' silence on a particular inatter can be taken as consent to a particular default rule only if two conditions are inet. First, we cannot infer from the parties' silence an indirect consent to a particular default rule from the overall mainfestation of assent to be bound if the parties had no reason to know of the rule. ${ }^{105}$ Second, we cannot infer such consent if contracting around the rule is so costly that there is hittle point in raising the issue in negotiation. I include in the latter category the cost of uncertain enforceinent. If, for exaniple, courts are very likely to view any effort to hquidate daniages as an unenforceable penalty clause, then it is tenuous to infer froin the parties' silence an indirect consent to a default rule that permits the court to measure contract daniages by the expectancy interest. In the presence of rules that are costly to discover or contract around, silence is highly anibiguous. It inay or may not signify consent to the imposition of the default rule. ${ }^{106}$

This means that when the transaction costs of discovering and contracting around the default rules are sufficiently low, a party's consent to be legally bound coupled with silence on the issue in question may well constitute consent to the imposition of the particular default rule that is in existence in the relevant legal systein. Under such circumstances, a consent to be legally bound can provide both a necessary and a sufficient consensual basis for enforcing the prevailing rule. As transaction costs increase, however, this inference becoines progressively weaker. At its weakest, we can only presuine a consent to the imposition of some set of default rules, in which case the enforcement

105 Varying degrees of requisite knowledge are possible, from "knowledge of a specific rule of contract law," to "knowledge of the existence of contract law." The latter can be inferred from evidence that the parties intended to be legally bound.

106 Cf. Charny, supra note 15:

The meaning attributed to words by most transactors and by a legal decisionmaker establishing a set of conventional (code) formulations will often coincide. ...

This occurs when three prerequisites are satisfied. First, the transactors advert to legal enforceability of their bargain. Second, transactors follow well-defined and efficient conventions for drafting contracts. Third, transactors can inform themselves of the set of background interpretive conventions.

Id. at 1851-52. 
of particular default rules is justified only if they are of a certain type. To determine which rules are justified by consent when transaction costs increase, it is necessary to understand how consent influences the choice of default rules. This will be discussed in Part III.

\section{Consent and the Choice Between Default and Immutable Rules}

Consent also explains why we should generally prefer default to immutable rules. Default rules have powerful advantages over immutable rules. For exainple, by holding promisors hable for only the foreseeable losses caused by their breaches, the rule of Hadley v. Baxendale ${ }^{107}$ creates two default rules. First, it provides a default rule that promisors are not hable for special damages-dainages that are not foreseeable because they would not ordinarily result from the breach-unless promisees notify them of the special losses that inay result from breach. ${ }^{108}$ This default rule provides an incentive for promisees for whom breach poses special risks to convey this information to the promisor who may then be in a position to take precautions to prevent the loss. ${ }^{109}$

1079 Ex. 341, 156 Eng. Rep. 145 (1854).

108 Federal Express "codifies" this limitation of liability on both the front and back of its airbill form (Federal Express Airbill, form \#137205 GBFE 10/91). On the front appears a passage under the following lieading (in bold, capital, and italicized letters): "SERVICE CONDITIONS, DECLARED VALUE AND LIMIT OF LIABILITY." The second paragraph begins as follows:

We will not be responsible for any claim in excess of $\$ 100$ per package, whether the result of loss, damage, delay, non-delivery, misdelivery, or misinformation, unless you declare a higher value, pay an additional cliarge, and document your actual loss for a timely claim. . . . Your right to recover from Federal Express for any loss, including intrimsic value of the package, loss of sales, incoine interest, profit, attorney's fees, costs, and other forms of damage whether direct, incidental, consequential, or special is limited to the greater of $\$ 100$ or the declared value specified to the left.

Similar language also appears on the back of the form under the lieadings (in bold, capital, and italicized letters) "LIMITATIONS ON OUR LIABILITY AND LIABILITIES NOT ASSUMED."

109 The account presented in the text is the standard economic analysis of the rule actually announced in the case. See Johnston, supra note 4, at 621 ("The basic notion that Hadley is efficient because it forces the revelation of private information regarding consequential loss and thereby facilitates optimal precautions against breacli is now the established economic understanding."). Johnston limiself takes issue with this account on the grounds that the actual rule in Hadley has evolved into a substantially different and, froin an econornic perspective, superior rule. Johnston argues that the standard account fails to adequately take account of the strategic considerations that block the revelation of information that the standard account says is induced by the Hadley rule. In Johnston's view, the rule which lias evolved from Hadley does liandle the problems created by strategic bargaining. That Federal 
The second default rule of Hadley holds that promisors are hable for all losses that are foreseeable-either because they are the natural consequences of breach or because notice of special damages was given by the promisee-unless they expressly disclaim hability. So, for example, Federal Express limits expressly its hability for breaching its on-time dehvery guarantee to providing a refund, and its total hability for losses caused by breach to $\$ 100 .^{110}$ This default rule that holds promisors hable for all foreseeable losses in the absence of agreement to the contrary reflects the common sense of what most parties would think it means to be legally bound. It thereby puts the onus on those who seek to deviate from this common expectation to mform the other party that their agreement is subject to different rules.

The advantages of the Hadley default rules are unobtainable, however, unless parties are free to mamifest their consent to terms different from those supplied by Hadley and to have a court honor their consensual choice. That is, unless the parties are free to deviate from many of the gap-fillers provided by contract law, the significant benefits of using default rather than immutable rules are lost. The key to obtaining the benefits of default rules, then, is to resist turning every gap-filling rule of contract law into an immutable rule.

This again requires us to understand why consent is the basis of contractual obhigation. In particular, as discussed in Part I, basing contractual obligation-including the ability to contract around the gap-filling default rules of contract law-on consent addresses the pervasive social problem of knowledge by harnessing the personal and local knowledge possessed by contracting parties, but which is not systemically accessible to central planners. A requirement of consent also copes with the pervasive social problem of interest by providing

Express perceives the need to expressly include the substance of the Hadley v. Baxendale rule on both the front and back of its agreeinent suggests that the prevailing default rule is something different. See supra note 108. Still, for purposes of this Article, it does not matter which account of the default rule established by this case is correet so long as one of thein is.

110 This expressed limitation of remedy appears on both the front and back of the form. See supra note 108 . On the front appears a passage under the following heading (in bold, capital, and italicized letters): "SERVICE CONDITIONS, DECLARED VALUE AND LIMIT OF LIABILITY." Id. The last paragraph reads: "In the event of untimely dehivery, Federal Express will at your request and with some limitations, refund all transportation charges paid. See Service Guide for further information." Id. Similar language also appears on the back of the form under the heading (also in bold, capital, and italicized letters), "MONEY-BACK GUARANTEE." Id. 
incentives for productive exchanges of entitleinents, by restricting exploitative expropriation of resources, and by protecting persons' expectations that they can safely rely on the future use of particular resources.

\section{Ameliorating the Conflict Between "Freedom from" and "Freedom to" Contract}

The default rules concept suggests three ways that a inanifested consent to be legally bound is theoretically significant. First, manifested consent is the crucial factor that justifies contractual enforcement-including the enforceinent of default rules. By distinguishing agreements that are enforceable from those that are not, manifested consent identifies those agreeinents that are subject to gap-filling. Second, under certaim circumstances, consent to be legally bound can justify the enforcement of the particular default rules in effect in a legal system. Finally, the functional analysis of consent is crucial to any justification of freedom of contract, the hiberal value implicit in the very concept of a default rule. Consent thus explains why gap-filling contract rules should be default rather than immutable rules.

This analysis helps illuminate the fanıus case of Sun Printing \& Publishers Ass'n v. Remington Paper \& Power Co. ${ }^{111}$ What so incensed dissenting Judge Crane was the fact that Judge Cardozo's majority allowed the seller, which had obviously inanifested an intention to be legally bound, to escape hability through the price gap in the agreement it had drafted. ${ }^{112}$ As Crane put it, "We must, at least,

111139 N.E. 470 (N.Y. 1923).

112 In Sun Printing, the buyer agreed to purchase a quantity of paper each month at a price that was to be agreed upon, but was to be no higher than the monthly price charged by the Canadian Export Paper Company (the "Canadian standard" price). When the seller breached, the buyer offered each month thereafter to pay the Canadian standard price then prevailing, which presumably was the highest price that could have been negotiated, thus apparently "curing by concession" the problem of indefiniteness arising from an "agreement to agree." Unfortunately, the contract specified in addition that the period of time for which the agreed upon price was to remain in effect was also to be agreed upon. Because of this (and because of the failure of the buyer to commit to paying the Canadian standard price for the duration of the contract), Judge Cardozo found the contract fatally indefinite notwithstanding that each month the buyer offered to pay the Canadian standard price then in effect. Although neither opinion considers the possibility, a "cure by concession" would have been accomplished had the buyer committed itself to pay for the duration of the agreement any monthly increases in the Canadian standard price, and continue to pay the mcreased price even if the Canadian standard price later fell. In this way, the seller could have done no better in negotiations regardless of how long the price agreed upon was supposed to remain in effect and cannot be 
start the examination of this agreenent by believing that these intelligent parties intended to make a binding contract. If this be so, the court sliould spell out a binding contract, if it be possible."113 Crane was loatli to let a party, particularly the drafting party, escape responsibility for its manifestation of intent to be legally bound through a gap in the inanifestation of consent.

Today, of course, courts would likely reacli a different outcoine by interpreting the Uniform Commercial Code (U.C.C.) to fill the price term gap. ${ }^{14}$ But because the gap-fillers provided by the U.C.C. are not available unless there is a inanifested intention to be legally bound, this result would be consistent with a consent theory. U.C.C. section 2-204(3) specifies: "Even thougli one or more terms are left open a contract for sale does not fail for indefiniteness if the parties have intended to make a contract and there is a reasonably certain basis for giving an appropriate remedy."115 The Official Cominent expands upon section 2-204(3) as follows: "If the parties intend to enter into a binding agreement, this subsection recognizes that agreeinent as valid in law, despite missing terms, if there is any reasonably certain basis for granting a reinedy."116 That the issue of contractual gaps is subordinate to the intent to create contractual relations is further reniforced by the following: "The inore terms the parties leave open, the less likely it is that they liave intended to conclude a binding

prejudiced by enforcing the sales agreement. The theoretical issue raised by Sun Printing is not, however, one of "cure by concession" in which the buyer resolves the indefiniteness or "gap" in the agreement by consenting ex post to a "gap-filling" term most favorable to the other side, but whether, in light of this gap, the buyer had a right to purchase the paper according to price terms speeified by a court-supphed default rule that had been consented to ex ante by reinaining silent on the issue.

113139 N.E. at 473.

114 See U.C.C. \$ 2-305 (1987). The U.C.C. provides that:

Speeial emphasis must be placed on the permissibility of omitting the price term in view of the insistence of solne courts on the express inclusion of this term even where the parties have contracted on the basis of a published price hist. In many valid contracts for sale the parties do not mention the price in express terms, the buyer being bound to pay and the seller to accept a reasonable price which the trier of the fact may well be trusted to determine.

Id. § 2-201 official cmt.

115 Id. § 2-204(3) (einphasis added).

116 Id. § 2-204 official cint. (einphasis added). 
agreement, but their actions may be frequently conclusive on the matter despite the omissions." 117

The dispute between Crane and Cardozo illustrates that the real controversy created by contractual incompleteness is not the miportance of consent to be legally bound, but whether more than this is required for an enforceable contract to exist. How much certainty of terms do we require before enforcmg an agreement to which parties have manifested an intention to be legally bound? Richard Speidel has characterized this as a conflict between the two aspects of the hiberal conception of contractual freedom: freedom to contract and freedom from contract. ${ }^{118}$ Crane's opmion can be seen as representing the view that a refusal to enforce the parties' agreement infringes the parties' freedom to make and rely upon an enforceable contract, something that they unquestionably intended to do. Cardozo's opinion, in contrast, represents the view that parties should be free from having terms to which they did not consent miposed on them by a court. In Crane's view the parties have created a legal relationship that requires gap-filling. In Cardozo's view, the parties have failed to make their own private law for the courts to enforce.

Richard Speidel claims that the "spirit of contract" has shifted away froin the "classical" theory of contract which, "despite its apparent emphasis on enforcement, provided considerable room for exit. In short, the key feature of the 'old spirit of contract' may have

117 Id. (emphasis added). There remains some anbiguity in this formulation. A "binding agreement" may mean an agreement that each party genuinely intends to perform without necessarily intending to be legally bound for nonperformance, in contrast to a tentative or preliminary agreement to which there has been no such commitment. The trouble with this definition of "binding agreement" is that "binding" adds nothing to the meaning of "agreement," just as a "binding" promise adds nothing to the definition of promise unless "binding" means enforceable. The inost sensible interpretation is that the term "contract" refers to "binding agreements" and by binding is meant "legally enforceable." In this way, under U.C.C. $\$ 2-204$, gap-fillers would not be available unless the "parties have intended to make a contract" meaning that they intended to be legally bound.

This is not to claim that the U.C.C. requires an intention to be legally bound before enforcing an obligation and thereby miplicitly adopts a consent theory of contract for all matters concerning contract formation. It is ouly to claim that the U.C.C. requires proof of an intention to be legally bound before its default rules may operate to fill any gaps in the parties' manifestation.

118 See Speidel, supra note 53, at 194 ("[T]he law of contracts . . . constantly reflects the tension between 'freedom to' and 'freedom from." "). For an account of the deeidedly different functions played by each of these aspects of the hberal conception of freedom of contract, see supra notes 52-53 and accompanying text. 
been the scope of 'freedom from' liability rather than the notion of enforcement underlying 'freedom to." "119 In contrast, Speidel characterizes the "new spirit of contract" reflected in such cases as Aluminum Co. of America v. Essex Group, Inc., ${ }^{120}$ as "a victory for enforcement over exit"121 — a victory that does "little damage to the requirement of consent in contract law." 122 Notwithstanding this cliaracterization of the "new spirit of contract" as reflecting the triumph of one aspect of contractual freedom over the other, Speidel concludes by echoing the old gap-filling conception of coercively "imposed" terms:

[T] he "new" spirit of contract is a form of tort-a duty of good faith in performance and enforcenent of a contract inposed without the parties' consent. This duty ... is one more limitation upon "freedom froin" contract and cannot be viewed with joy by those who celebrate the virtues of classical contract law. ${ }^{123}$

How does the treatment of default rules presented here help to resolve this seemingly mevitable tension between "freedom from" and "freedom to" contract? When the conditions described above are satisfied (that is, wlien there are accessible background rules that can be changed at reasonable cost), by reinaining silent parties can be said to have "really" consented to the imposition of a default rule as much as they consent to any other term of their agreement. ${ }^{124}$ Only when these conditions are not present or when an immutable background rule is imposed on the parties is the liberal principle of freedom froin contract thwarted. ${ }^{125}$

119 Speidel, supra note 53, at 198-99.

120499 F. Supp. 53 (W.D. Pa. 1980).

121 Speidel, supra note 53, at 199.

122 Id. at 207.

123 Id. at 208. For a spirited defense of the "contractual" or consensual basis of this duty of good faith in the performance and enforceinent of a contract, see Steven J. Burton \& Eric G. Andersen, The World of a Contract, 75 Iowa L. Rev. 861, 867 (1990) ("[I]ntention and expectations play the central role in good faith performance, material breach, and good faith enforcement.").

124 The issue of how the content of the default rules should be determined in hight of this overall consent will be discussed infra Part III.

125 If default rules are chosen in the manner described in Part III, however, their imposition nay still be justified as consensual, even if parties were ignorant of their existence at the time they remained silent. 
This point is inade by Clayton Gillette in his discussion of "[c]ontractual silence as [an] allocation of risk."126 As Gillette explains, "[v]iewing the allocational bargain as an attempt by parties to reduce the existence and consequences of risk and uncertainty, it follows that the parties will sometimes attempt to attain that result by imphicit allocations or by acceptance of state-imposed allocations." 127 Gillette takes issue with Speidel's view that contractual incompleteness creates "true gaps in the bargaining process that trigger judicial intervention" 128 that violates the principle of freedom from contract:

Viewed in this way, however, Speidel's inquiry may be off to a false start. If the exchange is, as Speidel assumes, a voluntary one between rational actors, then any "failure" to include specific terms or to consider a specific risk may itself be a voluntary part of the agreeinent. What the parties have agreed to, in effect, is to consider only certain risks and no others. The failure to allocate a risk in a voluntary bargain does not necessarily constitute a failure of agreement or of the bargaining process; it inay constitute a decision by the party who will suffer from the risk's inaterialization that the expected loss froin the risk is not worth the resources that would have to be invested to identify it and allocate it expressly, ${ }^{129}$

Although Gillette does not specifically use the term "default rule" until a later article, ${ }^{130}$ he is imphicitly applying the concept as a way of reconciling freedom from and freedom to contract. Given the existence of disceririble default rules, parties may rationally choose to leave their contracts "incomplete." This incompleteness does not, however, constitute a "true gap" that can ouly be closed by judicial impositions violative of the principle of freedom from contract.

126 Claytou P. Gillette, Commercial Rationality and the Duty to Adjust Long-Term Contracts, 69 Minn. L. Rev. 521, 534-40 (1985).

127 Id. at 535 (footnote omitted). Gillette's term "implicit allocations" corresponds to the term "implied-in-fact," while his phrase "acceptance of state-imposed allocations" refers to what are now called default rules. Although Gillette speaks of state "imposed" allocations, the parties can only be said to have "accepted" this allocation if the state allocation is by default rules rather than by immutable rules. While Gillette adopts the "default rule" terminology in later writings (see, e.g., Gillette, supra note 18), his earlier usage is itself instructive for it underscores the extent to which the voluntary nature of default rules was until recently hidden beneath the rhetoric of "state-imposed" gap-filling rules.

128 Gillette, supra note 126 , at 537 .

129 Id. at 538.

130 See Gillette, supra note 18. 


\section{Consent and the Choice of Default Rules: A Reply TO RICHARD CRASWELL ${ }^{131}$}

Some have argued that, althougli consent may underlie the enforcement of contractual commitments, it is deficient and requires supplementation because the default rules supplied by courts and legislatures are not based on consent but on some otlier reasons of principle or policy. Coleman, Heckathorn, and Maser, for example, respond to the argument made in Part II concerning consent to the jurisdiction of a legal system as follows:

[I]f by consenting to a contract, one consents to a jurisdiction's default rule, then one consents to whatever rule the court appliesfrom those rules aimed at reconstructing a hypothetical bargain to those imposing fair terms, to others imposing efficient terms, to those imposing obnoxious terms, and so on. ... If this argument works at all, it works too well. ${ }^{132}$

Richard Craswell has based virtually an entire article critical of philosophical theories of contract on this argument:

My thesis is that debates over the question of why promises are binding do much less than is commouly supposed to settle the role to be played by efficiency, non-economic values, or ethical theories generally in selecting contract law's background rules. More precisely, I have argued that certain answers to the question of why promises are binding do nothing to settle these larger issues. Theories that explain the binding force of promises by pointing to the value of individual freedom . . may well be valid answers to the question of why promises are binding. But ... freedom can usually be served equally well by any background rule, so some other value must be introduced to explain why any one rule ought to be chosen over any other. ${ }^{133}$

Arguing specifically against my consent theory, Craswell concludes:

Without a theory of interpretation, the ouly guidance we are left witls in selecting default rules is that the law should take an objective approach to interpretation. But to endorse an objective approach is

131 I wish to thank Richard Craswell and my colleague Steve Heyman for their most insightful suggestions concerning the thesis presented in this Section.

132 Coleman et al., supra note 12 , at 646 . They also argue that the argument does not work because parties have little or no choices among legal jurisdictions. For my reply see infra Part IV.

133 Craswell, supra note 16, at 528 (emphasis added). In the omitted portions of this passage, Craswell includes misrepresentation theories as suffering from the same defect. 
merely to identify one factor-the secret, subjective intention of either party-which should not be used as a reason for preferring one rule over another. It says nothing about which factors should be considered. It thus leaves unresolved all the debates concerning the role of efficiency as a goal of contract law, or the extent to which contract law should be shaped by redistributional concerns or other values. ${ }^{134}$

In this Part, I explain why this charge is false. I maintain that a consent theory of contract-including the functional account of consent presented in Part I-significantly influences, even if it does not always coinpletely determine, how we should choose ainong possible default rules.

Although Craswell has focused on that aspect of consent theory that accounts for the objective approach to interpretation, the answer to his challenge hes in the functional relationship in a consent theory between objective consent and subjective assent. I shall specify two justifications for choosing default rules that reflect the conventional expectations that attach to silence in the relevant community of discourse-what I call "conventionalist default rules." First, default rules should conform as closely as possible to the subjective agreement of the parties. Second, they should reduce instances of subjective disagreement about the terms of the agreement that are not reflected in the parties' manifested assent. These imperatives reflect the need to reconcile contract law's sometimes conflicting functions of addressing both the first-order problem of knowledge (by taking into account subjective consent to transfers) and the second-order problein of knowledge (by providing discernible action-guiding boundaries upon which a regime of stable expectations and rehance can be based).

\section{A. "Conventionalist" Default Rules and Subjective Agreement}

As previously discussed, a consent theory calls for an objective interpretation of contracts. Contracts are part of an entitlements scheme that performs a vital boundary-defining function, facilitatimg the orderly use of local and personal knowledge. ${ }^{135}$ Entitlements can-

134 Id. See also Charny, supra note 15, at 1818 ("As currently understood among lawyers, the predominant noninstrumental theories of contract are in large measure indeterminate as to the question of default rules.").

135 This is the "first-order problem of knowledge" discussed supra text accompanying notes 36-53. 
not perform this function unless persons can obtain knowledge of their requirements so that they can regulate their own behavior and rehably predict how others will behave. ${ }^{136}$ Because we never have direct and rehiable access to the hidden or subjective intentions of others, we can only rely on the reasonable meaning conveyed by a party's words and behavior. Contrary to Craswell's claims, the objective approach to contract does have important implications for the choice of default rules in a consent theory of contract. These implications stem from the fact of imperfect information.

The object of a consent theory is to enforce the inanifested intentions of the parties. Although a consent theory takes an objective approach for reasons noted in Part $I$, it is not indifferent to the fact that the objective meaning of consent is likely to correspond to the subjectively lield imtentions of the parties. Indeed, some of the functions performed by the liberal primciple of freedom of contract depend on this correspondence. For example, one of the functions of freedom to contract is to enable persons to exchange entitleinents they have for those that they subjectively prefer, thereby making them better off. ${ }^{137}$ One of the functions of freedom from contract is to require persons who seek to acquire the resources belonging to others to take into account the subjective preferences of the present right-holder. ${ }^{138}$ To perform either of these functions our objective imterpretation of assent should mirror as nearly as possible (subject to other constraints ${ }^{139}$ ) the subjective intentions of the parties. ${ }^{140}$

When there is a gap in manifested intent, it may be a true gap, in whicl case neither party lias any subjective imtentions. In this situation, botli parties' (nonexistent) subjective intentions will be satisfied

136 This is the "second-order problem of knowledge" discussed supra text accompanying notes 74-77.

137 See supra text accompanying notes 52-53.

138 See supra text accompanying notes 52-53.

139 See Scott, supra note 11, at 613-15 (discussing the drawbacks, in a regime of imperfeet legal enforcement, of particularizing default rules to more closely conform to specific circumstances).

140 As I have stated, "In a consent thcory ... contracts are interpreted with an eye towards honoring the actual intentions of the parties." Barnett, Consent Thcory, supra note 27, at 30607. What distinguishes a consent theory from a will theory is reflected in the sentence following the one quoted above: "But where the subjective intentions of one party have not been manifested to the other, only the 'reasonable' or objective interpretation of the commitment will establish the clear boundaries required by an entitlements approach." Id. at 307. 
equally by any default rule. ${ }^{141}$ It is also possible, however, even likely, that there are mutually shared tacit subjective intentions that cannot be established and that influence the ineaning of what has been inanifested. ${ }^{142}$ As Lon Fuller (no lover of legal fictions ${ }^{143}$ ) explanied:

Words like "intention," "assumption," "expectation" and "understanding" all seem to imply a conscious state involving an awareness of alternatives and a deliberate cloice among them. It is, however, plam that therc is a psychological state which can be described as a "tacit assumption" that does not involve a consciousness of alternatives. The absent-minded professor stepping from his office into the hall as lie reads a book "assumes" that the floor of the hall will be there to receive him. His conduct is conditioned and directed by this assumption, even though the possibility that the floor lias been removed does not "occur" to him, that is, is not present in his conscious mental processes. ${ }^{144}$

Fuller's insights are supported by modern psychological research focusing on the relationship between conscious and nonconscious thought processes. ${ }^{145}$ This relationship can better be understood by

141 In the next Section, I explain how a consent theory may also influence the choice of default rules where there is no subjective agreement between the parties. A consent theory accomplishes this by rccommending the choice of a penalty default rule designed to induce one party to inform the other of the terms that will govern their agreement when these terms conflict with normal expectations.

142 Cf. Charny, supra note 15 , at 1856 ("Understandings regarding any contingency not written into the formal contract arise locally as a matter of custom, tradition, received wisdom, widely shared but unarticulated assumptions, and so forth.").

143 See Lon L. Fuller, Legal Fictions (1967).

144 Lon L. Fuller \& Robert Braucher, Basic Contract Law 555 (1964). Ian Macneil has also stressed this insight by Lon Fuller concerning the role of tacit assumptions for contract theory. See Ian R. Macneil, The Many Futures of Contracts, 47 S. Cal. L. Rev. 691, $772-73$ (1974); Ian R. Macneil, Lon Fuller: Nexusist, 26 Am. J. Juris. 219, 222-24 (1981).

145 See Paul J. Heald \& James E. Heald, Mindlessness and Law, 77 Va. L. Rev. 1127, 1137 (1991) ("Decisionmaking proceeds from both conscious and nonconscious states of awareness." (footnote omitted)). The Healds refer to the latter type of decision making as "mindless":

[T]he scripts and schemas that guide a high proportion of human behavior are developed from experiences (personal and vicarious) and filed in our memory in categorized and labeled forms. Different sitnations have distinguishing features that trigger appropriate scripts. The process occurs in a mindless, nonconscious manner, and once imvoked, the script provides a map for subsequent behavior.

Id. at 1151. See also Daniel C. Dennett, Consciousness Explamed (1991). Building on recent research, Dennett theorizes that our "consciousness" is the way our minds have evolved to deal with the "competition among many concurrent contentful events in the brain ...." Id. at 275. He insists "that there is no motivated way to draw a lime dividing the events that are 
considering an analogy to video games that create fictional "worlds" sometimes called "virtual realities." Only a portion of the game's world appears on the screen (in "consciousness") at any particular time, but the portion that remaims out of sight still "exists" (though "nonconsciously"). The off-screen portion bears a constant "spatial" relationship to the portions of the world that is on the screen notwithstanding that it does not exist anywhere hiterally as a picture. Similarly, when using a word processor, the rest of one's document still exists even though only a portion of each page appears on the screen at any one time and the balance exists as magnetically recorded computer code, not actual text. ${ }^{146}$

Finally, consider an analogy to fiction. We can say with confidence that certain things are "true" about the fictional world of Sherlock Holmes and other things are "false" even when there is no reference to these facts in any of Conan Doyle's stories.

What is true in the story is much, inucl more than what is explicitly asserted in the text. It is true that there are no jet planes in Holmes' London (tliougli this is not asserted explicitly or even logically implied in the text), but also true that there are piano tuners (tliougl1 - as best I recall-none is mentioned, or, again, logically implied). In addition to wliat is true and false in the story, there is a large indetermmate area: while it is true that Holmes and Watson took the 11:10 from Waterloo Station to Aldersliot one summer's

definitely 'in' consciousness from the events that stay forever 'outside' or 'beneath' consciousness." Id.

146 The Healds draw the analogy this way:

The processes of categorical developinent, storage, and retrieval are soinewhat analogous to computer storage and retrieval systems wherein the lowest level of subdirectories contains the inost discrete categories (as in "letters," "speeches," "memos," and "manuscripts" stored in word-processing files) whereas the root directory is reserved for larger "chunks." A "path command" may be invoked to sort quickly through the various subdirectories to access the specific file (category) containing the data and associations sought.

Objects with characteristics perceived as similar but not identical comprise a conceptual category or subcategory, and categories may be "chunked" into more generic "prototypical" categories comprised of several lower categories that contain shared attributes. ...

Objects are not the only things categorized. We store memories of our actions and actions of others as well as images of many kinds, for example, situations and events, language and labels, scripts and schema.

Heald \& Heald, supra note 145, at 1140-41 (footnotes omitted). 
day, it is neither true nor false that that day was a Wednesday ("The Crooked Man"). ${ }^{147}$

Fictitious worlds are constructs of which only a fraction appears exphicitly at any given time. Similarly, the human mind can be viewed as creating a "virtual reality," an elaborate construct of the external world. Only a tiny fraction of this construct is present in consciousness at any given time. ${ }^{148}$

Contracts, too, can be understood as the enterprise of projecting into the future an imagined "world." As Steven Burton and Eric Andersen have explained: "Two persons can cooperate by jointly imagining a possible world and, by entering an agreenent with a promise on at least one side, committing theinselves to each other to bring that world into being by their actions." 149 Of inost relevance here is that this projected "world of contract" is usually the same as the present world of the parties in all respects except for the changes exphicitly identified by the agreeinent. ${ }^{150}$ The parties silently assume that which "is" will continue to exist. Significantly, inuch of what they assume is true of the present is only a tacit or subconscious assumption. In other words, contracting parties are often silenteven to themselves-about what they in fact beheve. ${ }^{151}$

This does not mean that these silent assuinptions are not real. ${ }^{152}$ Rather, they represent the immense "iceberg" of personal knowl-

147 Dennett, supra note 145, at 79. Dennett drew this analogy from the semantics of fiction. See, e.g., David Lewis, Truth im Fiction, 15 Am. Phil. Q. 37 (1978).

148 I am skeptical of legal theorists relymg heavily on knowledge imported from other disciplines. Too often the imported theories are highly distorted and serious intradisciphinary controversies about them ignored. Therefore, although the implications of modern psychological research cannot be dismissed as beyond the scope of this Article, at this juncture, the reach of this Article may have exceeded its grasp.

149 Burton \& Andersen, supra note 123, at 864. Compare Dennett, supra note 145, at 177 ("The key to control is the ability to track or even anticipate the important features of the environment, so all brains are, in essence, anticipation machines.").

150 See Burton \& Andersen, supra note 123, at 864 ("The imagined world may be hike the extant world at the time of the promises in all respects save two; for example, Crusoe's coconut can be imagined in Friday's hands while Friday's fish can be imagined in Crusoe's hands. Their pronnises to exchange a coconut for a fish constitute a joint commitment to bring that world into existence by the coordinated actions of performing the two promises.").

151 See Heald \& Heald, supra note 145, at 1154 ("In scriptive mode, we process and respond to information that we cannot articulate.").

152 Ultimately, for the thesis defended here, it may not matter whether these are "real" or merely external constructs. For what is at issue is the communicated meaning of silence. Therefore, even if these constructs are simply used to impute meaning to a person's silence, then they operate to fill the gaps in manifested assent regardless of whether they are "there" in 
edge $^{153}$ that hes submerged beneath the exposed "tip" of knowledge evident both to oneself and to others. ${ }^{154}$ As discussed in Part I, access to personal knowledge of any kind is highly limited. But because these assumptions are tacit and often nonconscious, they are notoriously difficult to prove directly-even the person possessing this sort of knowledge may be unaware of it. Moreover, tacit assumptions are by definition unexpressed, and thus they are not evidenced by some linguistic formulation. Indeed, tacit assumptions serve to modify the normal meaning of what has been manifested. As Fuller explained:

[A]n adoption of the "objective" standard does not make psychological fact completely irrelevant. In such a case we are, as it were, applying the truths of psychology hypothetically, and the more we can learn about the human animal and his motivation, the more effectively can we construct standards of "reasonable" behavior and "reasonable" expectations. ${ }^{155}$

In light of this, the parties' subjective consent is most likely to be satisfied by a default rule that interprets inanifested consent to reflect the commonsense or conventional expectations that likely are part of the tacit assumptions of particular parties. Where there is an unexpressed (and possibly nonconscious, but nonetheless genume) tacit assumption shared by both parties, it almost invariably reflects the commonsense expectations of the relevant community. ${ }^{156}$ "Common sense," as used here, simply means the sense of things that most people share in common. In the example given by Fuller, people com-

a person's subconsciousness. Still, if it can be said that people do in fact subjectively hold these tacit assumptions, this would minimize any claimed conflict between freedoin from and freedom to contract when such assumptions are used to interpret a party's silence.

153 See supra note 41.

154 Compare Burton \& Andersen's formulation:

It . . . is an easy inistake to suppose that a contract fails to provide authoritative guidance when it does not specify in all circumstances the rights and duties of the parties in objeetive behavioral terms. Such a imistake flows froin an inpoverished idea of the content of contractual obhigation. In practice, contract is inuch more than its expressed terms, interpreted hiterally. It is a nanifestation of intention to bring an envisioned world into being as a practical inatter.

Burton \& Andersen, supra note 123 , at 876.

155 Fuller \& Braucher, supra note 144, at 557.

156 It inay also reflect, however, a urique course of dealing that exists between the parties and, when this is shown to be the case, then this subjective agreenent will truinp the "conventional" meaning. See U.C.C. § 1-205(4) (1987) ("course of dealing controls usage of trade"). This is not really an exception to the conventionalist default rule, but a very narrow interpretation of the relevant coininunity of discourse. 
monly expect that the floor of the hallway that was outside their office door when they entered will still be there when they leave. That expectation is part of their elaborate and largely nonconscious mental construct of the world. The fact that this belief is unexpressed and nonconscious-one does not ordinarily think about it-does not mean that one does not believe it and, if asked, would not say that one beheved it.

This simple insiglit is crucial to the clroice of default rules. Suppose it was legally relevant to adopt a rule that would best capture most people's subjective, but unexpressed and possibly nonconscious understanding concerning the floor outside their office. A rule reflecting the parties' tacit expectations that the floor outside their office still exists is functionally superior to a rule that reflects some other assumption about the state of the floor. Because tacit factual assumptions color every manifestation of consent, contractual enforcement will correspond to the subjective imtentions of the parties only to the extent that default rules comport with the factual assumptions prevailing im the community of discourse to which the parties belong.

Neither when silence represents a true gap because the parties have no tacit assumption about the world, nor when it represents a tacit assumption that is actually shared by the parties, do we face the problem for which the objective theory is the solution: one party relying on the reasonable meaning of behavior while the otlier party has a subjective intention that differs from this meaning. Although the objective theory attempts to resolve disputes that arise from the subjective disagreement of contracting parties, situations where silence represents the subjectively-held tacit assumptions of both parties are situations of subjective agreement between the parties. The objective theory of contract is inapposite to this situation.

At this point, the functional analysis of freedoin of contract is again relevant. To address the first-order problein of knowledge as well as problems of interest, we both permit and require the consensual transfers of entitlements. Both of these functions are satisfied when the subjective assent of the parties is honored. Therefore, when there is no subjective disagreement between the parties, but instead the parties have a tacit subjective agreement, their silence should (all else being 
equal $^{157}$ ) be interpreted in a manner that is inost likely to reflect their actual subjective intentions. In other words, we should strive to reduce the probable discrepancy between the actual subjective agreement of the parties and the default rules that courts will use to interpret their silence and fill the gap in their inanifested consent.

Given that a default rule reflecting the coinmonsense expectations within the relevant community of discourse is likely to satisfy the parties' intentions as well (in the case of a true gap) or better (in the case where shared tacit subjective assuniptions are present) than any rival default rule, there is a strong reason to prefer it. This is particularly true in light of the fact that the legal system usually cannot know whether it is facing a situation of true gaps or tacit assumptions. If a goal of a consent theory is to have the law of contract honor the subjective consent of the parties to the extent possible in a world of limited access to personal knowledge of intentions, default rules reflecting the commonsense expectation within the relevant community of discourse will lead to fewer interpretive mistakes than soine other type of rule. ${ }^{158}$ To paraphrase Coleman, Heckathorn, and Maser, the connection between consent and default rules based upon commonsense expectations is epistemic, not analytic. ${ }^{159}$ The conventional understanding is evidence, perhaps the best and only evidence, of what parties with mutual subjective tacit intentions concerning a niatter arising in a gap nı the nıanifestation of consent actually agreed to.

The implied obligation of good faith performance illustrates how concern with reducing the disparity between objective and subjective assent properly influences the choice of backgronnd rules, in this case the imnutable rule provided by the Uniform Coniniercial Code: "Every contract or duty within this Act imposes an obligation of good faith in its performance or enforceinent."160 Every contract limits a party's freedon1. In particular, entering into a contract costs a party the opportunity to enter into another exchange in its place. This is

157 Factors I have in mind that would affect the scope of the principle enunciated in the text have to do with the costs of determining subjective assent.

158 This reason was stressed in Barnett \& Becker, supra note 27.

159 See Coleman et al., supra note 12 , at 645 (discussing the relationship between hypothetical rational bargaining and hypothetical consent).

160 U.C.C. $\S 1-203$ (1987). 
what James Buchanan has called the "cost of choice."161 For example, by committing to sell my house to you I incur the subjective cost of having to forgo the opportumity of selling it to another.

According to Steven Burton, ${ }^{162}$ when a contract grants some discretion in performance (as contracts almost always do), it is bad faith for a party to exercise this discretion to reclaim an opportunity she bargamed away when entering imto the contract. Implying a duty of good faith reflects the commonsense expectations of persons entering into a contract; ${ }^{163}$ failure to imply such a duty would give the party exercising discretion a right she had failed to obtain by bargaining. ${ }^{164}$

161 See Buchanan, supra note 59.

162 See Steven J. Burton, Breach of Contract and the Common Law Duty to Perform in Good Faith, 94 Harv. L. Rev. 369 (1980); Steven J. Burton, Good Faith Performance of a Contract Within Article 2 of the Uniform Commercial Code, 67 Iowa L. Rev. 1 (1981); Steven J. Burton, More on Good Faith Performance of a Contract: A Reply to Professor Summers, 69 lowa L. Rev. 497 (1984).

163 Burton and Andersen contend that this is not merely a inatter of conventional meaning, but is conceptual. That is, the very act of entering a contract involves parties forgoing soine opportunities. If no opportunities whatever are forgone, then there has been no contractual commitment. See Burton \& Andersen, supra note 123, at 869 ("In the abstract, good faith is so basic to contract that it amounts to the principle of promise-keeping itself . . .."). This contention is similar in its structure to my claim that any inanifested intention to be legally bound necessarily or conceptually entails a consent to some legal jurisdiction. If this claim is true, it suggests how conceptual understanding can assist us in determining the content of commonsense background behefs. See nifra Part V. It also provides a response to those who inay deny that there exists a universal conventional understanding that contracts must be performed in good faith. If we reject an overly ambitious good faith "morality" in favor of Burton's theory of good faith as conduct that does not seek to recapture forgone opportunities, we niay argue that, as a conceptual matter, to consent to a contract obligation is to consent to perforin in good faith.

164 Although this background rule is immutable rather than a default rule it is not hard to see why. Could we imagine a competent party to a contract consenting ex ante to let the other party perform in bad faith? If any such expressed clause appeared in a writing, we would strongly suspect either that it went unread or that sone serious defect in the bargaining process was responsible for its inclusion. This example of enforcing the "commonsense" expectations of niost persons illustrates that the imphications of a consent theory for background rules is not limited to default rules. The background rule iniplying a duty of good faith is immutable and cannot be overcone even by the bargaining behavior of one of the parties. When an attenipt to expressly contract around this duty occurs, we would question whether consent-as traditionally policed by rules governing conipetency, duress, and undue influence-was really present. Even if we could not directly establish the presence of one of these defects, we inay have very good reason to beheve that, as a general nuatter, allowing enforcement of such a clause would likely lead to serious enforcenient errors im many cases. In sum, enforcement of this sort of expressed clause is more likely than not to be contrary rather than consistent with the (ex ante) consent of the party against whom it is being enforced. 
The duty of loyalty of an agent to the principal is an example of a default rule that reflects the commonsense expectations or tacit assumptions of persons entering into an agency relationship. One default rule that stems from this duty is the so-called "dual agency rule" that an agent cannot act on behalf of an adverse party to a transaction connected with his agency without the consent of his principal. ${ }^{165}$ In other words, the normal expectation is that such conflicts of interest are not consented to by the primcipal, but that the presumption established by this default rule can be rebutted by a proof of actual consent to such an arrangement. In sum, fewer enforcement errors in assessing consent will occur by adopting this default rule than a default rule that permitted such conflicts of interest unless a primcipal expressly bargained to restrict this practice. ${ }^{166}$

Partnership law also provides an exainple of a default rule that defies common sense. The normal default rule, reflecting the common sense of most partners, is that partners divide any profits or losses that may occur according to their share of the partnership. So two equal partners divide profits and losses equally. ${ }^{167}$ When, however, one partner has contributed only money and the other partner has contributed ouly labor, upon termination of the partnership, the Uniforin Partnership Act (U.P.A.) obhigates the partner contributing ouly labor to compensate the other partner for half of his lost monetary contribution notwithstanding the fact that this party loses all of her labor as well. This result occurs due to the operation of three distinct default rules each of which makes sense nnder normal circumstances. First, capital contributions of partners are considered debts of the partnership that must be repaid before profits or losses are distrib-

165 See Restatement (Second) of Agency $§ 391$ (1957):

Acting for Adverse Party without Principal's Consent

Unless otherwise agreed, an agent is subject to a duty to his principal not to act on behalf of an adverse party in a transaction conneeted with his agency without the principal's knowledge.

166 The problem of enforcement error is one of two problems of power that every society mnst confront once it legitimizes the use of force to solve the compliance problem. (The other is the problem of enforcement abuse.) Although I cannot discuss the inatter here, the problem of enforcement error may cause us to modify our conceptions of justice and the rule of law that are otherwise satisfactory in handling the problems of knowledge and of interest.

167 See Uniform Partnership Act § 18(a) (1914) ("Each partner shall . . . share equally in the profits and surplns remaining after all habilities, includimg those to partners, are satisfied; and must contribute towards the losses, whether of capital or otherwise, sustained by the partnership according to his share in the profits."). 
uted; ${ }^{168}$ second, each partner is jointly liable for this debt; ${ }^{169}$ and third, "[n]o partner is entitled to remuneration for acting in the partnership business . . ."170 In cases where one partner has invested only money and the other only labor, some courts have simply adopted the counter-intuitive result of the coinbined effects of these three rules. ${ }^{171}$ Others, however, have resisted this result and have adopted instead a default rule that reflects the common sense of this special circumstance. "[W] other contributes services, then in the event of a loss each would lose his own capital-the one his inoney and the other his labor."172

To conclude, just as it has long been considered mefficacious to base contract only on the subjective will of the parties, so, too, would it be inefficacious to attempt to rest contract solely on soine sort of objective meaning that is wholly separate from subjective will. A consent theory recommends the adoption of "conventionalist" default rules precisely because of the dual relationship between subjective and objective consent. ${ }^{173}$ The idea is to adopt default rules that tie as closely together as possible these two ways of viewing consent. ${ }^{174}$

\section{B. 'Conventionalist" Default Rules and Subjective Disagreement}

Suppose, however, that parties do not share the same factual assumptions about the world. To see how a consent theory may con-

168 See id. $\S \S 18(a), 40(b)$.

169 See id. § 15(b) ("All partners are liable ... [j]ointly for all other debts and obligations of the partnership ....".).

170 Id. $\S 18(\mathrm{f})$.

171 See, e.g., Richert v. Handly, 330 P.2d 1079 (Wash. 1958). In Richert, the court was quite explicit about using the Uniform Partnership Act to supply a default rule in the absence of any expressed agreement of the parties.

172 Kovacik v. Reed, 315 P.2d 314, 316 (Cal. 1957) (en banc).

173 I discuss the distimction betwecn objective consent and subjective assent in Part IV.

174 Craswell contends that I think "certain default rules are somehow inherent in the concepts einployed by [a consent] theory and therefore do not require normative justification of any sort." Craswell, supra note 16, at 526. In the only example froin my writings that he uses to illustrate this observation, however, (a special problein of undisclosed agency law that I need not rehearse here), lie misunderstands iny argument. I was not arguing that the particular construction of the agency relationship I favored was the only logically possible coustruction or that it was "somelow inherent" in the concepts of consent I was employing. Rather, I thought that this construction was implicit insofar as it represented the conventional coinmonsense assumption made by persons entering into agency relationships-the assunption refleeted in the default rules provided by the law of agency. After private correspondence on this question Craswell and I are now in agreement that this was simply a misunderstanding of iny original arguinent that arose froin a lack of clarity in my presentation. 
tribute to the proper choice of background rules in such circumstances, consider once more the two default rules provided by the case of Hadley v. Baxendale. ${ }^{175}$ According to Craswell, a consent theory is irrelevant to determining, for example, whether expansive hability for all foreseeable losses should be imposed on Federal Express (which would then have to expressly limit its responsibility) or whether Federal Express should confront a default rule of limited hability (that would apply unless the customer expressly bargains for more expansive hability). In Craswell's view, this choice must be based on some notion of efficiency or some other substantive theory, but not on consent.

A consent theory is indifferent to the choice of default rules, however, only on the assumption that it is rational for both parties to incur the costs of learning the existing default rule and of bargaining around it. If this were always the case, from the perspective of consent, we could equally well place the burden on a promisee or on the promisor to expressly bargain around the default allocation of hability. ${ }^{176}$ But this assumption about rationality is often unwarranted.

With sinall one-shot transactions it nay be irrational for either party to pay a lawyer to provide information concerning the default rules. Put another way, in light of the stakes involved, it may be rational for the parties to remain ignorant of the background rules. Under these circumstances, for reasons previously discussed, a conventionalist default rule based on the colnmonsense expectations of most persons would be most likely to accurately reflect the tacit subjective agreennent of these rationally ignorant parties. In this manner, a gap between manifested consent and subjective assent would likely be narrowed.

In some common and definable circumstances, the cost of obtaining knowledge of the background rules of contract law can justify adoptning a conventionalist default that reflects the commonsense understanding of rationally ignorant parties. In situations where the coninionsense meaning elnbodied in a conventionalist default rule reflects the subjective understanding of only one of the parties, such a

1759 Ex. 341, 156 Eng. Rep. 145 (1854).

176 Even in this situation, a consent theory would argue the importance of establishing a clear default rule by convention. For a system of entitlements to perform its boundarydefining function, there inust be soine accessible default rule for parties either to accept or contract around. Otherwise, persons will not know where they stand. 
rule operates as what Ayres and Gertner call a "penalty default." A penalty default is

designed to give at least one party to the contract an incentive to contract around the default rule and therefore to choose affirmatively the contract provision[s] they prefer. ... [P]enalty defaults are purposely set at what the parties would not want-in order to encourage the parties to reveal information to each other or to third parties (especially the courts). ${ }^{177}$

Something like this "penalty default" function of legal rules was contemplated by Lon Fuller in his discussion of the relevance of tacit assumptions to law:

[T]he law has two rather antithetical tasks with respect to human behavior: 1) that of adjusting its rules to the expectations and intentions of "reasonable" men, and 2) that of disciplining human behavior and guiding it into proper channels. ...

The law has always to weigh against the advantages of conforming to the laymen's assumptions, the advantages of reshaping and clarifying those assumptions. ${ }^{178}$

Conventionalist default rules that reflect the tacit subjective assent of the parties perform the first of these two functions. The second function is performed by conventionalist default rules that reflect the prevailing expectations in the commumity of which the rationally ignorant party is a member.

Although Ayres and Gertner see the device of penalty defaults as serving a variety of informational purposes, a consent theory offers a particular justification for using conventionalist default rules as penalty defaults. When one party is rationally ignorant of the background rules of contract and the other party is not-that is, the other party is either knowledgeable or irrationally ignorant-default rules can reduce the instances of subjective disagreements arising between parties who otherwise are manifestimg mutual consent.

Compare repeat players, like Federal Express, who can amortize the cost of obtaining knowledge of the background rules over a great

177 Ayres \& Gertner, supra note 4, at 91. Robert Scott refers to this as an "informationforcing default rule." See Scott, supra note 11, at 609 ("Certain default rules are set, not because they represent the ultimate allocations preferred by most bargainers, but rather because they are best suited to inducing one party to share important information with the other.").

178 Fuller \& Braucher, supra note 144, at 557-58 (einphasis added). 
many transactions, with the one-shot user of express mail for whom it would be irrational to hire a lawyer to discover what the normal default rule governing hability was. In other words, it is rational for many parties to remain ignorant-"rationally ignorant," as it wereof the background legal rule. Because they would simply assume that, by its silence concerning hability for breach, Federal Express is implicitly consenting to hability for all foreseeable losses when it expressly promises to "absolutely, positively" get your package dehivered overmight - this, after all, is the commonsense meaning of these words-these rationally ignorant parties would fail to bargain for increased hability.

Under circumstances where it is rational for one party to obtain knowledge of the default rules and the other party to remain ignorant of them, the substance of the default rules is highly relevant to any effort to reduce the imcidence of subjective disagreeinent between the parties. Where, for exainple, the default rule is soinething other than the commonsense or conventional expectation held by persons in the position of the rationally ignorant party, and such terms favor the interests of the rationally imformed party, then, although they hold different intentions, both parties are likely to remain silent on this issue. The rationally ignorant party will not expressly bargain around the default rule because she does not expect an undesirable rule. The rationally informed party will not expressly bargain for the default rule, because the favorable rule will apply by default. In this way, the silence of the parties will mean different things to each party and a subjective disagreement between the parties will result.

When a "misunderstanding"179 arises concerning the meaning of the terms of the parties' agreeinent and it is engendered by tlie choice of a default rule that is counter-intuitive for the rationally ignorant party, rational ignorance of the law may be an excuse. ${ }^{180}$ Adopting a

179 See Restatement (Second) of Contracts $\$ 20$ (1979); Allan Farnsworth describes a misunderstanding as "a situation in which two parties attach different meanings to their language." Farnsworth, supra note $26, \S 9.2$, at 679 . In the situation described in the text, there is a misunderstanding of the meaning of the parties' silence that is created by the choice of default rules.

180 See Lambert v. California, 355 U.S. 225, 228 (1957) ("The rule that ignorance of the law will not excuse' . . . is deep in our law . . . . On the other hand, due process places some limits on its exercise. Engrained in our concept of due process is the requirement of notice."). The issue in Lambert was whether the defendant, a convicted felon, had any reason to think that failing to register as a felon with the City of Los Angeles might be a crime. The decision 
conventionalist default rule that reflects the commonsense expectation of the community of discourse of which the rationally ignorant party is a member would reduce the instances of this sort of subjective disagreeinent. Such a rule functions as a penalty default, creating an incentive for the rationally informed party to express a preference for the term that deviates from this common sense. In this way, the rationally informed party is induced to inform by its bargaining behavior the rationally ignorant party of the terms of their agreement and reduce the incidence of subjective disagreement.

For example, a default rule in favor of awarding damages for all foreseeable losses caused by breach requires rationally knowledgeable Federal Express to notify the rationally ignorant customer by its bargaining behavior-that is, with its form contract-that it seeks to deviate from the commonsense norm of liability for foreseeable loss. With such an express clause, those consumers who are not harmed much by late delivery get the benefit of a lower price, while thoseneeding extra protection must compensate Federal Express for its increased risk by purchasing insurance for nondelivery. Although it inay be rational to remam ignorant of the background rules if knowledge of these rules can be obtained ouly by consulting a lawyer, the saine cannot be said of the costs of reading a sufficiently clear, exphicit agreement.

Even a so-called "adhesion" contract can provide valuable information about the terms governing the agreenent. Much "boilerplate" in a form contract either promulgates background rules that, according to the consent theory developed here, should ordinarily reflect coinmonsense expectations, or provides details where there is no commonsense or tacit understanding on such matters. In a form contract laden with such noncontroversial clauses, however, unless the pres-

in Lambert could be interpreted as holding that where common sense provides no clue that a particular act or failure to act may be illegal, it is simply too costly to expect a rational person to inquire as to the possibility of such a requirement. In Lambert, the court observed that "circuinstances which might move one to inquire as to the necessity of registration are coinpletely lacking." Id. at 229 . While normally the onus is on the citizens to inform themselves of the law's requirements, when imposing counter-intuitive obligations on rationally ignorant citizens, the burden shifts to the State of California to provide soine notice to the defendant. See also United States v. International Minerals \& Chein. Corp., 402 U.S. $558,565$ (1971) ("[W] $]$ here ... dangerous or deleterious devices or products or obnoxious waste Inaterials are involved, the probability of regulation is so great that anyone who is aware that he is in possession of thein or dealing with thein inust be presumed to be aware of the regulation." (einphasis added)). 
ence of a clause that deviates from commonsense expectations is brought to the attention of the other party by its prominence ${ }^{181}$ and even by a requirement of some additional formality, ${ }^{182}$ the drafting party has no reason to believe that the other party consented to it. ${ }^{183}$ Sucl terms are, to use Todd Rakoff's expression, "invisible."184

What is true of the measure of relief for breach lolds true for the form of rehef as well. The commonsense meaning of a commitment to perform is that the promisor ${ }^{185}$ is obliged to actually perform. Most persons untutored in the fine poimts of contract law think they are bargaining for performance, not the option of the promisor to perform or pay expectation dainages. Rationally ignorant promisees will assume that the cominonsense expectation governs their transaction. Should they desire a specific performance remedy, they will not bargain for a different clause because they are unaware that such bargaining is necessary.

In this situation, a default rule limiting relief to money dainages would fail to induce bargaining behavior to clarify the inatter. Assuming the promisor desires the dainages remedy, she will knowingly or unknowingly obtain this implied clause without having to pay extra for it. Unlike the typical cause of contractual incompleteness, this cominunicative discrepancy is not based on any ignorance con-

181 See, e.g., U.C.C. § 2-316(2) (1987) ("[T]o exclude or modify the imphed warranty of merchantability or any part of it the language inust mention merchantability and in case of a writing must be conspicuous, and to exclude or modify any implied warranty of fitness the exclusion inust be by a writing and conspicuous."). Federal Express has done this when the terms of its form contract deviate from common sense. See supra notes 108, 110.

182 See, e.g., U.C.C. § 2-205 (1987) ("An offer by a merchant to buy or sell goods in a signed writing which by its terms gives assurance that it will be held open is not revocable . . . but any such term of assurance on a form supphed by the offeree inust be separately signed by the offeror."). Although increased formality may well be justified, by increasing the cost of contracting around the rule such a requirement reduces to some degree the inference that parties have consented to the default rule by remaining silent.

183 To posit the paradigm case, a party does not manifest consent to an obscure term that deviates from common sense and is hidden in pages of fine print simply by signing such a form.

184 Todd D. Rakoff, Contracts of Adhesion: An Essay in Reconstruction, 96 Harv. L. Rev. 1174,1251 (1983) ("Visible" terms are all bargained terms and "those for which a large proportion of adherents (although not necessarily all) may be expected to have shopped .... The invisible terms are, quite simply, all the rest."). I would expand the set of visible terms to include terms that refiect the common sense in the relevant community of discourse and those counter-intuitive terms rendered visible by virtue of their conspicuousness or increased formality.

185 Although I do not adopt the promise model of contract, I do adopt for converience the conventional promisor-promisee terminology. 
cerning the future, but on ignorance of the default rules provided by the legal system, coupled with the fact that this knowledge does not come free. On the other hand, a default rule that the provider of goods or corporate services, ${ }^{186}$ for example, would have to specifically perform such services unless an express clause limits hability to money damages would either (a) give both parties what they really want or (b) force the party seeking to limit rehief to money damages to educate the rationally ignorant consumer as to what has really been consented to. I offered much the same analysis of specific performance in an earlier article:

Persons with common sense-that is, those who have not taken a first-year contracts class (or been counseled by a lawyer who has)would naturally assume, for example, that when a good is purchased the purchaser obtains a right to the good. They would not assume that the seller has an option to dehiver or pay damages-if damages can be proved-unless the victim can prove that the good is unique.

... This becomes a problem when one party is knowledgeable about contract law and obtains the commitment of the ignorant party at a lower price than would be obtained if the rules of contract remedies better comported with common sense. While some disparity of information between parties is mevitable and irremediable, information disparities concerning the law of contract itself should be minimized. ${ }^{187}$

Thus, given this conventional expectation, a consent theory of contract recommends a presumption in favor of specific performance of sales contracts. ${ }^{188}$

Both the Hadley and specific performance examples illustrate that, when the cost of obtaining knowledge of the default rule supphed by a legal system is sufficiently high (as it typically is for one-shot players), the rationally ignorant party is most likely to interpret the other party's silence as meaning consent to a default rule that conforms to the normal commonsense expectation. Therefore, when one-shot

186 For a discussion of the moral and legal difference between corporate and personal services, see Barnett, Inalienable Rights, supra note 27, at 197-201.

187 Id. at 183.

188 I go on to observe, however, that when a good is readily available from other suppliers and the subjective cost of specific performance imposed on the seller increases substantially, it may no longer be safe to presume an implicit agreement by silence to specific performance. See id. at $196 \mathrm{n} .59$. In sum, the presumption of specific performance can be rebutted by a showing of such circumstances. 
players are contracting with each other or with repeat players, the default rule should reflect this everyday common sense and the onus should fall upon the repeat player to contract around the rule. This choice of default rules induces one party to educate the other so that the manifested agreement is brought into closer correspondence with the subjective intent. Were this not the rule, then the communicative function performed by the objective approach would be unnecessarily deficient. As Karl Llewellyn put the inatter in 1931: "If the other party appeals to law, then to the extent that the obligation is viewed by layman and by law-inan differently, I shall either get less, or be held to inore, than the custoinary understanding calls for." 189

Although it is rational for the repeat player to obtain knowledge of the background rule and irrational for the one-shot player to do so, this disparity of knowledge between the two parties has nothing to do with either the relative wealth or the bargaining power of the parties. It is usually rational for repeat players-even those who are relatively poor-to ainortize over inany exchanges the cost of obtaining this information by retaining legal expertise. It is usually irrational for one-shot players-even those who are relatively wealthy-to do so. On the other hand, it is rational even for one-shot players of modest means to make a significant investment in obtaining legal knowledge when the stakes involved in the transaction are very high as, for example, when one purchases a house or incorporates a business.

Thus, contrary to Craswell, ${ }^{190}$ a consent theory does say soinething quite significant about the choice of default rules. ${ }^{191}$ It is true that when both parties are rationally informed about the background rules, it matters hittle to these parties which default rule is chosen. Rationally informed parties are free to choose a term that is efficiency maximizing or one that is perceived by them to be fair. But here a consent theory is not so inuch indifferent to the choice of default rule as it is indifferent to the terms that rationally knowledgeable parties substitute for a default rule adopted because it reduces misunderstandings between differently situated parties.

189 Karl N. Llewellyn, What Price Contract?-An Essay in Perspective, 40 Yale L.J. 704, 713 (1931).

190 See Craswell, supra note 16, at 523-28 (criticizing iny consent-based theory of contract).

191 This is true whether or not further considerations should also be taken into account when settling upon a set of default rules. 
Craswell might respond that this entire line of argument is some sort of efficiency analysis and therefore invokes a principle other than that of consent to justify a preference among default rules. This response would miss the basic thrust of a consent theory of contract both as originally presented and as expanded upon here. My account of consent stresses that contractual obligation cannot be considered outside the context of a system of entitlements. As I have said: "The process of contractual transfer cannot be completely coinprehended ... without considering more fundamental issues, namely the nature and sources of individual entitlements and the ineans by which they come to be acquired." 192 And a complete understanding of entitlements requires a functional analysis. ${ }^{193}$ A consent theory does provide reasons for selecting from among possible default rules, even if these reasons will not always be dispositive. ${ }^{194}$

Iromically, some law and economics scholars have maintained that efficiency theories are unable to generate a single best default rule to govern the allocation of risk between the parties. Unlike a consent theory that seeks to identify the commonsense expectations that are implicit in the parties' silence in the absence of any bargaining, an efficiency analysis seeks to discern the term for which most parties would have bargamed. ${ }^{195}$ Clayton Gillette argues that:

\footnotetext{
192 Barnett, Consent Theory, supra note 27, at 294.

193 See Barnett, Internal \& External Analysis, supra note 27, (discussing the difference between functional and abstract analyses).

194 Craswell might also respond that I have adopted what he calls an "existing expectations" approach. See Craswell, supra note 16, at 505-08. But, "[i]f we must rely on sociological investigation to identify the set of possible background rules, and also to tell us which set of rules applies in any particular case, then sociology is doing virtually all of the work involved in fulfilling the needs of contract law." Id. at 508. I hope that, by now, the answer to this objection is apparent. First, consent provides a necessary justification for contractual enforcement of some set of default rules. Second, under certain conditions consent provides a sufficient justification for enforcing promulgated default rules. Third, where these conditions do not obtain, consent offers a sufficient justification for enforcing conventionalist default rules. For this objection to stand, therefore, great weight must be placed on the word "virtually" in the passage quoted above.

195 There is a subtle difference between the conventionalist default rules I advocate and socalled "inajoritarian default rules" advocated by efficiency theorists. Conventionalist default rules reflect the prevailing understanding or expectations within a community of discourse. Majoritarian default rules reflect the hypothetical bargain that two rational persons would (but did not) reach. For a critique of the prevailing economic approach to hypothetical bargains and an alternative, see Charny, supra note 15. I discuss the epistemic relationship between hypothetical and actual consent in Randy E. Barnett, Rational Bargaining Theory and Consent: Default Rules, Hypothetical Consent, the Duty to Disclose, and Fraud, 15 Harv. J.L.
} 
once we relax assumptions about risk-neutral decision-makers who seek to maximize expected utility, we cannot readily discern a majoritarian default rule of cooperation or egoism from a general investigation into risk attitudes. Transactional structures provide some hints but also suffer from sufficient ambiguity to preclude an authoritative default rule based on the parties' intent. ${ }^{196}$

Whether or not Gillette is correct, it is not enough for Craswell to argue that a consent theory cannot by itself generate default rules. It may be that no single theory or method can accomphish this task. The root of Craswell's difficulty may well be his implicit commitment to a single "best" methodology. ${ }^{197}$

\section{Summary}

To summarize, I argued in Part I that, to the extent possible, any systein of allocating resources sliould make full use of local and personal knowledge possessed by widely dispersed individuals. The best and perhaps the only way to accoinplish this is to recognize mdividual and associational ownership of all resources, and then to refuse to let any resource be used or transferred witliout the consent of the owner. The difficulty comes in defining what counts as consent. At a minimum, resources cannot be used or transferred over the express objection of the owner, as this would clearly permit transfers that failed to take account of the owner's personal and local knowledge. If the owner is silent, lowever, we need a system of default rules to decide when the owner should be treated as liaving consented to the transfer.

In selecting default rules, there are three relevant cases to consider. First, in cases wliere both parties are rationally informed and can be counted on both to know the law and to contract around any default rules that do not reflect their subjective preferences, whatever default rule the law selects can be viewed as consensual. In these cases, one

\& Pub. Pol'y (forthcoming Summer 1992). There I contend that methods of discerning hypothetical consent may provide a surrogate for actual consent in the absence of empirical evidence to the contrary. For a brief discussion of this methodological issue, see infra Part V.

196 Gillette, supra note 18, at 574; see also Baird, supra note 1, at 592-93 ("I agree with Gillette that the choice between the two starting points is not obvious. ... [W] cannot know how these choices are made as a matter of [economic] theory alone .....").

197 For a discussion of the need to diversify one's analytic methodology, see Barnett, Chickens \& Eggs, supra note 32; Barnett, Internal \& External Analysis, supra note 27; Barnett, Virtues of Redundancy, supra note 32. For a theory of hypothetical bargains based on diverse types of arguments, see Charny, supra note 15. 
party or the other will contract around any default rule that does not suit them, and the resulting contract will usually reflect each party's local and personal knowledge. Even in these "easy" cases, however, gaps in agreements are inevitable due to the problems of knowledge and interest discussed in Part I. When such gaps appear, default rules reflecting the common sense of the parties' community of discourse are inore likely to reflect the subjective understandings of the parties than any other default rule.

Second, if only one party can be counted on to know the law, the law should adopt a conventionalist default rule reflecting the commonsense understanding of the commumity to which the rationally ignorant party belongs. If this term is objectionable to the knowledgeable party, it will then exphicitly contract around the defanlt rule, and the process of explicitly contracting around that default rule will call the new rule to the attention of the rationally ignorant party, thereby giving that party a chance to object as well. In this way, conventionalist default rules serve as penalty defaults to reveal personal and local knowledge, and reduce tlie likelihood of subjective disagreements.

Third, there are cases where neither party can be counted on to know the law or to contract around an unacceptable default rule. In this situation, the parties' rational ignorance prevents the law from using eitler of the ineclianisms just described-that is, inechanisms that depend on one party or the other explicitly contracting around an unattractive rule- to make sure that eacli party's local and personal knowledge will be taken imto account. If the parties tacitly sliare some subjective assuinptions about the issue in question, lowever, the law should adopt a default rule that tracks their shared tacit assuniptions, because sucli a default rule is most likely to satisfy the parties' subjective intentions and thereby reflect their consent.

Fimally, when two rationally ignorant parties liold inconsistent assumptions, a consent theory recommends two responses. ${ }^{198}$ First, when one of the parties' subjective assumptions conforms to that prevailing in the relevant community of discourse, the objective interpretation of contracts now surfaces. A party is entitled to rely on the conventional or "reasonable" meaning even when the otlier party

198 I am assuming that neither party is subjectively aware of the other party's tacit assumption. When parties hold conflicting tacit assumptions and, for some reason, one party becomes aware of the other party's assumption and remains silent, the actual knowledge of one of the parties renders the silence of the other party unainbiguous. 
holds to a deviant assumption. In these situations, there is no objective ambiguity if a unique meaning of silence clearly prevails in the relevant community. Second, when there is no dommant convention on the subject we may say that both parties' differing tacit assumptions are reasonable. When a genume objective ambiguity exists, two parties with inconsistent tacit understandings of some material issue have simply failed to reach a consensual agreement. This situation would then be treated in a consent theory as it was in the classic case of Raffles v. Wichelhaus ${ }^{199}$ and as it is by the Restatement: as a "misunderstanding." 200 Such a conclusion does not mean that any loss must simply lie where it fell. Rather, the law of rescission would apply and parties would be returned, as nearly as possible, to the status quo ante. ${ }^{201}$

Of course, we must acknowledge that it is extraordinarily difficult for third parties to assess whether parties really held inconsistent tacit assumptions. Perhaps the best way of handling such claims is, once agam, to enforce a conventionalist default rule reflecting the prevailing commonsense meaning, uuless satisfactory proof is presented that

199 Raffles v. Wichelhaus, 2 H. \& C. 906, 159 Eng. Rep. 375 (Ex. 1864). In Raffles, the defendant refused to accept delivery of cotton transported to England on a ship named Peerless, claiming that he had subjectively assumed that the cotton would arrive on a different ship of the same name. There were in fact two such ships and apparently no course of dealing or trade custom available to resolve this objective ambiguity. Finding for the defendants, the court apparently accepted the following argument from defense counsel:

There is nothing on the face of the contract to shew [sic] that any particular ship called the "Peerless" was meant; but the moment it appears that two ships called the Peerless were about to sail froin Bombay there is a latent ambiguity, and parol evidence inay be given for the purpose of shewing [sic] that the defendant meant one "Peerless," and the plaintiff another. That being so, there was no consensus ad idem, and therefore no binding contract.

Id. at 907-08, 159 Eng. Rep. at 376. The judges' deeision in this case was ridiculed by Grant Gilmore. See Grant Gilınore, The Death of Contract 35-44 (1974). For a response, see A.W. Brian Simpson, Contracts for Cotton to Arrive: The Case of the Two Ships Peerless, 11 Cardozo L. Rev. 287, 324 (1989) ("[I]t is perfectly plain that in arrival contracts where ship and port were named, the identity of the carrying vessel was of central importance."). For American cases which adopt Simpson's view in different contexts, see Kyle v. Kavanagh, 103 Mass. 356 (1869) (concerning land sale contract); Oswald v. Allen, 417 F.2d 43 (2d Cir. 1969) (concerning sale of coin colleetion).

200 Restatement (Second) of Contracts $\$ 20$ (1979) ("There is no inanifestation of mutual assent to an exchange if the parties attach inaterially different meanings to their manifestations ...."); see also Farnsworth, supra note $26, \S 7.9$, at 508 ("The inost satisfactory rationale [for the Raffles decision] is that offered by the Restatement Second . ...").

201 See Restateinent (Second) of Contracts $\$ 20$ cint. d (1979) ("The basic principle governing inaterial misunderstanding is ... no contract is formed ...."). 
there was no agreement as to a particular meaning. Such an approach acknowledges the difficult knowledge problem involved in determining the conflictimg tacit assumptions and presumes, in the interest of reducing the incidence and severity of enforcement errors, that the tacit assumptions of the parties reflected those shared in the relevant community of discourse. To rebut this presumption, a party seeking to avoid the contract would have to prove that the parties held conflicting assumptions about a inaterial fact.

\section{Is Consent to Default Rules Really Consent?}

We are now in a position to understand how it is that enforcing default rules when parties remain silent on an issue can be justified as consensual. First, as explained in Part II, the institution of contract is invoked by the inanifestation of intention to be legally bound. Without this threshold inanifestation of consent, there is no justification for enforcmg contractual obhigations. So long as the costs of learning the content of default rules and of contracting around thein are sufficiently low, silence by the parties in the face of a default rule can constitute consent to its imposition.

Second, as was explained in Part III, even where these conditions do not obtain, the parties' manifestation of consent should be interpreted using conventionalist default rules that attempt to tie the ineaning of manifested consent as tightly as possible to the parties' subjective intentions. Conventionalist default rules bring objective manifestations and subjective assent closer together in two ways: (a) they capture the ineaning of the parties' shared tacit assumptions so that enforcement is more likely to refiect the subjective agreeinent of the parties, and (b) they act as penalty defaults by reducing the instances of subjective disagreennents that may arise between rational parties with asymmetric knowledge of the legal background rules.

In suni, consent plays a justificatory role at two distinct levels. The manifestation of intention to be legally bound is the type of consent that gets contract off the ground, while nested within this overall consent are default rules that are chosen to reduce the disparity between the objective meaning of consent and the subjective intentions of the parties. The manifestation of intention to be legally bound is a necessary condition of contractual obligation and, when parties are rationally informed, a sufficient justification to enforce the particular default rules in effect when the contract was forned. When, however, either 
or both parties who have manifested their intention to be legally bound are rationally ignorant, only conventionalist default rules can provide a sufficient consensual justification for enforceinent.

Soine are likely to remain skeptical about the contention that what I ain calling a consent theory of contract is based on "real" consent. They may argue that the analysis presented here proves too little because silence cannot constitute genuine or subjective consent to default rules about which one is entirely iguorant. ${ }^{202}$ On the other hand, they may argue that this approach proves too inuch because if parties consent to any default rule or even immutable rule that the courts inay impose, this cannot be a true theory of consent.

There are two distinct respects in which these criticisins miss the genuine nature of the consent in my consent theory of contract. First, these objections assume too rigid a dichotomy between subjective and objective consent. Second, consenting to jurisdiction does not mean that one consents to any default rule a legal system inay seek to impose. The objective meaning of such consent is constrained, but the absence of competition in the provision of law inay render this meaning unduly ambiguous.

\section{A. The Relationship Between Manifested and Subjective Assent}

The objection that parties cannot be said to genumely consent to an obligation when they do not have the obhigation specifically in their minds, and therefore that the analysis presented here proves too hittle, assumes an exclusively subjectivist conception of consent. A "will theory" traces the obligatory nature of contracts to the fact that parties have subjectively chosen to assume an obhigation. ${ }^{203}$ According to this conception of consent, when one does not subjectively consent one has not "really" consented. Although there are few will theorists these days, many scholars, perhaps most, still assume that purely subjective consent is the only type of consent that can matter.

According to Charles Fried, for example, only the enforceinent of subjective will is contractual. ${ }^{204}$ When there is no subjective agree-

202 They may bolster this by claiming that contracting parties only rarely have the background legal rules in mind. But see Heald \& Heald, supra note 145, at 1156 ("[S]tudies conducted by asking respondents what they 'know' about the law should be discounted.").

203 Barnett, Consent Theory, supra note 27, at 272-74.

204 Fried, supra note 9, at 61-62. 
ment, only "noncontractual principles"20s are available for resolving the dispute.

In the face of a claim of divergent intentions, the court imagines that it is respecting the will of the parties by asking what somebody else, say the ordinary person, would have intended by such words of agreement. This may be a reasonable resolution in some situations, but it palpably involves imposing an external standard on the parties. ${ }^{206}$

When default rules allocate risks, according to Fried, the parties "may deserve what they get, but not because it is a risk they have chosen to run. ... [T] [Tis deserving is not based on their consent ...."207 From the other end of the ideological spectrum, Ian Macneil takes the same position. "The greatest [legal fiction] in American law is the objective theory of contract. The classical American contract law is founded not upon actual consent but upon objective manifestations of imtent ... [that] include whole masses of contract content one, or even both, parties did not know im fact."208

Yet a consent theory of contract is not a "will theory."209 As explaimed in Part I, consent perforins important social functions within a theory of just resource entitlements. To handle the secondorder problem of knowledge, persons are held responsible prima facie for creating an appearance of consent to create legal relations, notwithstanding any subjective reservations they may harbor. ${ }^{210}$ The

205 See id. at 61 ("Another of the classical law's evasions of the inevitability of using noncontractual principles to resolve failures of agreenent is recourse to the so-called objective standard of interpretation.").

206 Id.

207 Id. at 62.

208 Ian R. Macneil, Contracts: Adjustment of Long-Term Economic Relations Under Classical, Neoclassical, and Relational Contract Law, 72 Nw. U. L. Rev. 854, 884 (1978) (einphasis added); see also Macneil, supra note 7, at 592 ("When a subjective inecting of the minds became too narrow a concept upon which to base complete presentiation, the contract structure shifted to an objective theory of contracts . . . ."). As I demonstrate elsewhere, however, although Macneil appears to equate consent with conscious subjective assent when he criticizes "classical" and "neoclassical" contract theories, when developing his own theory he is either nore ambivalent about consent or he adopts a view of consent that is closer to mine. See Barnett, supra note 7.

209 See Barnett, Consent Theory, supra note 27, at 300-07.

210 As I have explained in my earlier writings:

The boundaries of individual discretion that are defined by a system of clear entitlements serve to allocate decision-making authority among individuals. Vital information is thereby conveyed to all those who might wish to avoid disputes and respect the rights of others, provided they know what those rights are. Potential conflicts between persons who might otherwise vie for control of a given resource are 
obligations recognized by contract law are not the same as those entailed by the institution of promising. Our subjectively-made promises may create moral obligations for us to fulfill our commitment. The moral basis for the legal commitment entailed by contracts, however, is, in part, that contracts serve to coordinate resource use by establisling appearances that people can rely upon. Like property generally, ${ }^{211}$ contractual commitments communicate a inessage to otliers and one is responsible for the content of the message that one voluntarily has communicated.

In light of the second-order problem of knowledge, normally this content is interpreted objectively. It is imterpreted not according to any idiosyncratic meaning subjectively held by the speaker, but according to the meaning given by the relevant community of discourse. But this is not to say that subjective assent is irrelevant to a consent theory of contract. In Part III, I identified at least two important connections between subjective assent and objective consent. First, where tliere is tacit subjective agreement between the parties, enforcing default rules that reflect conventional understanding is likely to reflect subjective assent. Second, whiere consensual disagreement exists, enforcing conventional default rules functions as a penalty default, encouraging greater correspondence between inanifested and subjective assent. The objection that consent to unknown default rules cannot be true consent falls sliort when the default rules one consents to are chosen to reflect as closely as possible the subjective intentions of the parties.

Perhaps the close functional relationship between objective and subjective consent is obscured by the misleading nature of this tradi-

thus avoided. Therefore, an entitlements theory demands that the boundaries of protected domains be ascertainable, not only by judges who must resolve disputes that have arisen, but, perhaps more importantly, by the affected persons themselves before any dispute occurs.

In contract law, this informational or "boundary defining" requirement means that an assent to alienate rights must be manifested in some manner by one party to the other to serve as a criterion of enforcement. Without a manifestation of assent that is accessible to all affected parties, that aspect of a system of entitlements that governs transfers of rights will fail to achieve its main function.

Id. at 301-02.

211 See Carol M. Rose, Possession as the Origin of Property, 52 U. Chi. L. Rev. 73, 78-79 (1985) ("Possession now begins to look even more like something that requires a kind of communication, and the original claim to the property looks like a kind of speech, with the audiencc composed of all others who might be interested in claiming the object in question."). 
tional distinction. The objective meanings that pervade a community of discourse reside often tacitly $\mathrm{m}$ the minds of the persons who comprise that cominumity. Put another way, when the objective meaning of any communicative action is at issue, this inquiry must be informed by evidence of the subjective intentions of particular persons. A fortiori, the same is true of interpreting manifestations of consent. Conversely, people do not have subjective intentions wholly imdependent of the community of discourse to which they belong. One can never pursue one side of this dichotomy without at some point having to confront the other. ${ }^{212}$ According to Burton and Andersen, "two persons cannot contract unless they participate in a social practice of contracting. . . . The intention of the act of promising is the world represented by the terms of the promise, interpreted in accordance with the conventions of the relevant language community . . .."213

Burton and Andersen's analysis is much the same as Dennis Patterson's "Wittgensteinian" approach to contract theory. ${ }^{214}$ Patterson mamtains that "reality is a social process of conventions which are

212 Steven Burton has made this point well in his amusing analysis of "The Case of the Hoinunculean Explorers":

[T] he question is, what is the concept of assent that's being employed when Professor Linzer or Professor Macneil asserts that mutual assent is not "really" there when the objective theory is used. What is the concept of "real" consent that's presupposed when that assertion is made?

I suggest that there's an interesting assumption that's being made about what would count as real consent. It involves a conceptual division between the bodies that manifest intentions through gesture, conduct, speech, etc., and the mind as something else that has intentions. ...

So, if our bodies shake hands, we have an objective assent, right? And if our homunculi shake hands, then we have subjective assent. Somehow the real assent isn't there on the objective theory, because maybe our hoinunculi didn't shake hands. If it's just our bodies, then there is a false assent, as opposed to the real one that happens when our homunculi sliake liands.

This is really a crazy way of thinking about how we operate when we engage in contracting behavior. ... You can never have a real assent, if that's how you conceive of real assent.

Steven J. Burton, Comments on Professor Linzer's Paper, 1988 Ann. Surv. Am. L. 199, 201-02 (emphasis added). I would add that a conception of consent that fails to distinguish between consensual and nonconsensual acts is not only "crazy," it is useless.

213 Burton \& Andersen, supra note 123, at 864. If there is any difference between Burton and Andersen's view and mine, it is that I may place greater einphasis on the distinction between the social practice of promising and the social practice of contracting.

214 See Dennis M. Patterson, Wittgenstein and the Code: A Theory of Good Faith Performance and Enforcement under Article Nine, 137 U. Pa. L. Rev. 335 (1988). 
not 'agreed to' but shared."215 Consequently, what parties do "agree to," particularly when they are silent, must be interpreted in light of these assumptions about reality that they share. These assumptions are captured in the prevailing conventions in the relevant community of discourse. ${ }^{216}$ Arthur Corbin once wrote in a similar vein that

the parties occasionally have understandings or expectations that were so fundamental that they did not need to negotiate about those expectations. When the court "implies a promise" or loolds that "good faith" requires a party not to violate those expectations, it is recognizing that sometimes silence says more that [sic] words . ...217

\section{B. Consent to Immutable Rules and the Cost of Exit}

As was explained in Part II, when one consents to leave the realm of unenforceable commitments and enter the realm of legal enforcement, one necessarily consents to the apphication of legal standards in the event a dispute arises. These standards include the background rules that fill gaps in the parties' manifestations of assent. But perhaps this view proves too much. If consent to be legally bound implies a consent to any rules about which one remains silent, then by consenting to be legally bound has one not only consented to those default rules, but also to those imphed-in-law immutable rules that are imposed?

There is a ready answer to this question. Clearly, silence im the face of a default rule one can change ineans something significantly different from silence in the face of a rule that one cannot contract around. Or, perhaps more accurately, under conditions where a background rule cannot be altered by a manifested expression to the contrary, the objective ineaning of silence is anbiguous. It may mean subjective consent, but it equally may mean grudging acquiescence to a rule that one does not subjectively consent to. When background rules are immutable, we cannot as readily interpret silence as consent to their imposition.

215 Dennis M. Patterson, Law's Pragmatism: Law as Practice \& Narrative, 76 Va. L. Rev. 937, 942 (1990).

216 Provided that one keeps its limitations in mind, the objeetive-subjeetive dichotomy remains a useful way to explicate problems of contractual interpretation. Consequently, I shall continue to use it here.

217 Arthur Corbin, Corbin on Contracts $\S 570$ (Colin K. Kaufman ed., Supp. 1984) (emphasis added). 
Consider a legal system that refuses to enforce liquidated damages clauses that would reveal parties' actual preferences regarding the measure of recovery. Given such a regime, we still may be correct im presuming that the expectancy measure of damages is what most parties who are silent on the issue implicitly have chosen by remaining silent, but we are denied access to a pool of exphicit choices to help us confirm our niterpretive hypothesis. Moreover, we know that the parties' silence may also be a product of the fruitlessness of taking the trouble to negotiate an express clause that is unlikely to be enforced. Or consider the meaning of consent to be married in a legal regime that refuses to enforce privately negotiated marriage contracts. Is consent to be legally married really consent to all the default terms that the state supphies? Perhaps so, but other interpretations suggest themselves as well.

Thus arises the second criteria of inferring consent fron silence, nientioned in Part II. Silence ineans consent to a particular existing default rule only when the cost of discovering and contracting around the rule is sufficiently low. The cost of "contracting around" the existing package of default and immutable rules by resorting to extralegal metlods of assuring performance is exceedingly high, however. The choice to acquiesce to the legal background rules more closely resembles the duress of the gunman's demand of one's inoney or one's life than it does consent. This suggests a new avenue for default rules that has yet to be explored by default rule theorists.

Namely, to date it has been assunied that the entire set of contract rules supplied by a legal system is immutable ratlier than itself a default rule. ${ }^{218}$ When the choice of an entire set of background rules is immutable, lawmakers have no rehable market information about the set of rules that commercial parties actually want. They inust instead rely entirely on the assistance of legal theorists or lobbyists to tell them what the proper mix of default and immutable rules should be. Lawinakers face a serious knowledge problein. Should the wrong rules be chosen, or should lawinakers erroneously decide in favor of

218 A rare exception to this normal bias can be found in Coleman et al., supra note 12 , at 647 ("To feel comfortable with the claim that by contracting parties consent to the relevant default rule, we would have to assume something like a competitive market in authoritative jurisdictions. Then, the parties would choose jurisdictions based, among other things, on the default rule in effeet."). 
immutable rules rather than default rules, then contracting parties subject to its jurisdiction are stuck with the results.

Moreover, as Frank Knight argued, a meaningful power of exit is one important component of the concept of political freedom. "[E]ffective freedom depends upon an alternative open to the nonconforming individual of leaving the group witlout suffering loss or damage. In fact, freedom is chiefly a matter of 'competition' between groups for members ...."219 In addition to "hiteral freedom of action by individuals and free groups," and "equal participation in the activities of lawmaking," Knight mamtained that "since coinplete unanimity is not usually to be had, complete freedom implies the riglit and the power to leave the group, hence to join other groups, and eventually to form groupings at will."220 Thus, according to Kniglit, a person who may not "opt out" of a social arrangenent is, to this extent, unfree. Although the notion that genuine consent implies the existence of meamingful alteruatives is often stressed in discussions of socalled contracts of adhesion and in the context of doctrimes of duress and unconscionability, tlie idea that, in a free society, persons should have tlie power and riglit to contract around tlie background rules supplied by a legal system is rarely discussed.

Suppose, however, that court systems with differing sets of laws freely competed witli each other for customers in mucli the way states compete for businesses to incorporate (and then litigate) in their jurisdictions. ${ }^{221}$ Sucl1 a "common legal order containing diverse legal systems"222 would be, to use the terminology of Lon Fuller, less "vertical" and more "horizontal". ${ }^{223}$ To a limited extent, some such competition between states is possible today but, because legal sys-

219 Frank H. Knight, The Planful Act: The Possibilities and Limitations of Collective Rationality, in Freedom and Reform: Essays in Economics and Social Philosophy 398, 416 (Liberty Press ed. 1982).

220 Frank H. Knight, The Sickness of Liberal Society, in Freedoin and Reform, supra note 219 , at 440,465 .

221 See Ralph Wimter, Private Goals and Competition Among State Legal Systems, 6 Harv. J.L. \& Pub. Pol'y 127 (1982). I speculate about how such a "nonmonopolistic legal order" would work in Randy E. Barnett, Pursuing Justice in a Free Society: Part Two-Crime Prevention and the Legal Order, 5 Crim. Just. Ethics 30, 37-47 (1986). A recent and more elaborate treatment of this thesis can be found in Bruce L. Benson, The Enterprise of Law: Justice Without the State (1990).

222 Harold J. Berman, Law and Revolution: The Formation of the Western Legal Tradition 10 (1983).

223 See Fuller, supra note 75, at 233. 
tems receive their mcome largely from taxes rather than court fees, the incentive for competitive behavior among present legal systems is very limited. In contrast, much of what we call the common law was originally adopted from the law merchant and evolved when Enghish legal systems were very much in competition with each other for business. ${ }^{224}$

With greater competition among legal systems for the busmess of enforcmg contracts, we could expect a market solution-or rather solutions-to the problem of picking default rules. If meaningful competition among legal systems existed, commercial parties would choose those legal systems that offer them the best overall package of default and immutable rules. Under these conditions, a general consent to be legally bound, as discussed in Part II, might be construed as mcludimg a genuine consent even to those immutable rules that one cannot contract around. 225

As was seen im Part $I$, the act of consenting reveals important information concerning the personal and local knowledge of individuals and associations. The same holds true when seeking knowledge of the appropriate mix of default and immutable background rules supphied by a legal system. Unfortunately, in the absence of the vital information provided by consumer choices in a market for legal jurisdictions, a manifestation of assent to be legally bound is rendered more ambiguous than need be and we are forced to rely on other sources of knowledge. It is to this issue I now turn.

224 See Berman, supra note 222, at 10 ("Perhaps the most distinctive characteristic of the Western legal tradition is the coexistence and competition within the same community of diverse jurisdictions and diverse legal systeins."); Benson, supra note 221, at 61 ("There was always the threat of competition from private merchant courts, and if the royal courts wanted the merchants' business they had to enforce law to the merchants' satisfaction."); R.H. Helmholz, Assumpsit and Fidei Laesio, 91 Law Q. Rev. 406 (1975) (describing how competition between the common-law courts and the ecclesiastical courts led the common-law courts to expand protection of informal promises).

225 Even then, however, consent to be legally bound would still not mean a blanket consent to anything that a court may happen to do. When I expressly consent to jurisdiction, do I imphicitly or silently consent to any legal procedure, regardless of its fairness? For example, do I miplicitly consent to a procedure that bases its decisions upon race, gender, or religion? Do I imphicitly agree to a procedure that decides claims of right by the flip of a coin? Or does my consent not imphicitly assume the existence of what most would regard as fair or "due" process? Given that any implication of meaning ean be in error, which implication is the most likely to reflect the meaning of my consent? To minimize the incidence and severity of erroneous enforceinent and thereby advance the interests of justice, the conventionalist default rules discussed in Part III would provide this "due process." 


\section{Conclusion: Common Sense and Common LaW}

In this Article, I have attempted to explain how the new heuristic of default rules is more conducive to viewing consent as the heart of contract than the old imagery of gap-filling. I have discussed at considerable length the important social functions performed by making contractual consent a requirement of contractual enforcement. In particular, the hiberal conceptions of "freedom from" and "freedom to" contract address the pervasive social problems of knowledge and of interest. Under certain circumstances it is meaningful to say that one's silence in the face of default rules that one can change constitutes consent to the apphication of such rules. Fimally, I have used this functional analysis to show how the consensual basis of contractual enforcement should influence our choice of default rules.

I have offered several reasons why a consent theory supports choosing default rules that reflect the commonsense expectations of persons in the relevant community of discourse. With a default rule that reflects commonly-held expectations, when both parties are rationally ignorant neither is likely to be disappointed and the transaction enforced is likely to represent the consent of the parties. When one party is knowledgeable and the other is not and the knowledgeable party seeks soinething other than the default rule, she will engage in bargaining that will educate the rationally ignorant party about the rule and narrow any gap that may exist between subjectively held and objectively manifested intentions. Finally, when both parties are knowledgeable of the background default rule (which is likely to occur when both are repeat players or when the stakes are sufficiently high) they are free to alter it to better serve their purposes. Their silence indicates their consent to the enforcenient of the rule.

The analysis presented here, however, raises serious questions that are not addressed. How are the so-called "commonsense" expectations of parties to be determined? What exactly is the "relevant coinmunity of discourse'? What if parties are not ineinbers of the saine commumity or are niembers of more than one? How is a judge or legislature-or, for that matter, the American Law Institute, which actually inakes most of our private law today-supposed to go about answermg these questions? Traditionally, the parties' intentions were determined by looking at their expressed terms, their course of deal- 
ing, ${ }^{226}$ and the usage of trade, ${ }^{227}$ in this order. ${ }^{228}$ The Uniform Coininercial Code highlights the relationship between course of dealing and the interpretation of silence:

Where the contract for sale involves repeated occasions for performance by either party with knowledge of the nature of the performance and opportunity for objection to it by the other, any course of performance accepted or acquiesced in without objection shall be relevant to determine the ineaning of the agreement. ${ }^{229}$

Ultimately, determining the course of dealing and usage of trade is a factual inquiry. For example, courts can determine the course of dealing froin witness testimony and records of prior transactions. Usage of trade can be discovered by taking specialized evidence from witnesses or by reviewing einpirical research. Although it is perfectly appropriate for courts and legislatures to engage in empirical factfinding to determine the commonsense expectations of the particular parties to a contract dispute, when determining the commonsense content of default rules we may look to additional sources as well.

In the absence of proof of particular trade usage, courts can engage in what Ian Macneil has called "casual empiricisin"230 and what others call practical "wisdom." To the extent that judges are selected

226 U.C.C. $\S 1-205(1)$ (1987) (defining "course of dealing" as "a sequence of previous conduct between the parties to a particular transaction which is fairly to be regarded as establishing a common basis of understanding for interpreting their expressions and other conduct." (emphasis added)).

227 Id. § 1-205(2) (defining "usage of trade" as "any practice or method of dealing having such regularity of observance in a place, vocation or trade as to justify an expectation that it will be observed with respect to the transaction in question.").

228 See id. $\$ 1-205(4)$ ("[E]xpress terms control both course of dealing and usage of trade and course of dealing controls usage of trade."); Restatement (Second) of Contracts $\S 203(\mathrm{~b})$ (1979) ("express terms are given greater weight than course of performance, course of dealing, and usage of trade, course of performance is given greater weight than course of dealing or usage of trade, and course of dealing is given greater weight than usage of trade").

229 U.C.C. $\S 2-208(1)$ (1987).

230 This method of determining commonsense expectations may be the best we can expect from any legal system. Sec Ian R. Macneil, Efficient Breach of Contract: Circles in the Sky, 68 Va. L. Rev. 947, 953 n.25 (1982) ("Casual empiricism' is not a pejorative in my vocabulary; indeed, when used by wise people its other name is wisdom."). As he explains:

Most human knowledge, even in the rationalistic empirical present, is casually empirical, and we could not he otherwise. (Even the ready availability of sources of systematic knowledge does not mean that such knowledge is actually aequired and used, or once it is aequired, that it is remembered in ways rendering its subsequent recall anything but casual.) Casual empiricism, therefore, cannot be discarded from our ealculus, particularly respecting social knowledge. 
from the relevant community of discourse, they may discover the commonsense understanding of the parties-particularly the understanding of rationally ignorant parties-by introspection. ${ }^{231}$ I take some solace from the fact that common-law judges have been finding the "common sense" of the situation for centuries by relying, in part, on their intuitions. The problems with relying solely on intuitions, however, are well-known. ${ }^{232}$ Intuitions must be verified by more abstract or formal modes of reasoning, such as the constraints provided by traditional methods of legal reasoning. ${ }^{233}$

Of course, as discussed in Part IV, we are largely demied what is probably the most important source of knowledge of the meaning of parties' consent to be legally bound: the information revealed by a choice among legal jurisdictions. Consent to jurisdiction would serve the same information revealing, aggregating, and dissemmating functions as consent to sell one's house. Such market information could provide an important check on legislative or judicial determination of commonsense meaning.

In the absence of market choices revealing, dissemmating, and aggregating actual intentions, we may be able to reduce the incidence and severity of enforcement errors by relying on abstract theoretical surrogates for actual consent that attempt to construct the "hypothetical consent" of most contracting parties. Two such methodologies

Ian R. Macneil, Relational Contract: What We Do and Do Not Know, 1985 Wis. L. Rev. 483, 510 n.115 (emphasis added).

231 Unfortunately, while judges may be good surrogates for the rationally ignorant consumer, they are often deficient interpreters of more specialized usages of trade. For this reason Karl Llewellyn, the author of the Uniform Commercial Code, advocated that disputes be decided by merchant juries rather than by judges. See Dennis M. Patterson, Good Faith, Lender Liability, and Discretionary Acceleration: Of Llewellyn, Wittgenstem, and the Uniform Commercial Code, 68 Tex. L. Rev. 169, 202-03 (1989).

232 See, e.g., Richard A. Wasserstrom, The Judicial Decision: Toward a Theory of Legal Justification 95-96 (1961) ("Intuitions are essentially private affairs. They are difficult to obtain; they are even harder to repeat and thereby verify. ... Unless one has had a comparable intuition, the word of the 'imtuitor' must be taken both for the fact that he has had the vision and for the fact that he has imterpreted its commands faithfully.").

233 See Heald \& Heald, supra note 145, at 1163 ("Intuition ... may generate a prehimiary hypothesis that, depending on the novelty of the situation, may require conscious consideration before a judgment is made."). For an account of how legal reasoumg fulfills this function, see Steven J. Burton, An Introduction to Law and Legal Reasoning 9-82 (1985) (describing the use of analogical and deductive reasoming). 
are the abstract conceptualizing of some inoral theory ${ }^{234}$ and the formal reasoning of economic analysis. ${ }^{235}$ The results of these analyses of hypothetical consent may be seen as evidence of actual consent on issues about which the parties are silent and about which we lack information concerning courses of dealing or usages of trade. ${ }^{236}$

This is, however, a funny kind of "evidence." Perhaps it is more accurate to say that in the absence of empirical evidence of what actual parties in the relevant community of discourse mean when they consent in a particular situation, we will presume that they intended the default rule suggested by these abstract modes of analysis. Such a presumption would reflect our judgment that the simplifying assumptions at the heart of any abstract method of reasoning capture essential qualities that all or most persons share im common and, for this reason, are likely to yield good predictions about actual intentions.

That abstract methods of analysis are simply presuinptive surrogates for evidence of actual meaning im no way deprecates the practical value of such methods to a legal system or to legal theorists. Despite decades of cries for more empirical research into contracting practice, such research is still rare. And the epistemic function of a free market $\mathrm{m}$ legal jurisdictions is largely thwarted by the monopohistic legal regimes in which we all hive. Therefore, if consent is to be given a meaning that corresponds to the actual understanding in the

234 See, e.g., Peter Benson, Abstract Right and the Possibility of a Nondistributive Conception of Contract: Hegel and Contemporary Contract Theory, 10 Cardozo L. Rev. 1077 (1989). For my reply to Benson, see Barnett, Internal \& External Analysis, supra note 27.

235 For examples of efficiency analysis of default rules, see authorities cited supra notes 4, 11-18. For a "rational bargaining" approach to determining hypothetical consent, sce Coleman et al., supra note 12 . See also, Heald \& Heald, supra note 145, at 1169 ("[P]sychology and sociology enrich our understanding of the common law. Yet they do not threaten the explanatory power of the economic model . . . . Given the workability and simplicity of the model, fine tuning seems unnecessary.").

236 See Epstem, supra note 17, at 106 ("[W] strong evidence of what these parties did, in fact, agree to where there is silence or ambiguity."). Compare Charny:

Language carries with it a wide range of implicit connotative assumptions. It is taken to be situated in a complex set of conventions that constitute the expressive or referential power of even short simple phrases. Once this view of language is adopted, it would enhance autonomy, within the liberal conception, to enforce the imtentions recognizable under more sophisticated theories of interpretation. It is wrong not to honor what the parties "would have agreed to" if that hypothetical agreement is part of what the parties did agree to.

Charny, supra note 15 , at 1825 n.45. 
relevant community, some more abstract method of approximating this meanimg without costly empirical research or market information may be quite valuable imdeed.

Of course, each of these sources of knowledge presents obvious difficulties. Theorists operating within a particular mode of analysis will often disagree about which default rule is to be preferred. And probleins arise as well when different modes of analysis recommend different default rules. But though different methods may conflict, when viewed as "redundant" or potentially coinplementary and reinforcing methods of discovery, they can also contribute to knowledgeable determinations of the tacit dimension of consent. As I have stressed elsewhere:

The virtue of adopting multiple or redundant modes of analysis is, then, two-fold: (a) convergence (or agreement) among them supports greater confidence in our conclusions; and (b) divergence (or conflict) signals the need to reexamine critically the issue im a search for reconciliation. In sum, convergence begets confidence, divergence stimulates discovery. ${ }^{237}$

Although more attention to these methodological questions is surely warranted, when it comes to the question of whether and how courts can identify the commonsense expectations of the parties, we can be somewhat coinforted by the proposition that "that which can be shown to exist, is also shown to be possible." The best explanation I can find for many, if not most, of the background rules provided by the common law of contract and agency is that they reflect the common sense of the community in which they are applied ${ }^{238}$ - a common sense that includes norms of both fairness and efficiency. Many of these primciples originated with the competitive law merchant that preceded the growth of the common law. Many more were determined im an era when common-law courts coinpeted for legal business with other legal systems and therefore had a far greater incentive than today to be sensitive to the expectations of both parties. With this as

237 Barnett, Virtues of Redundancy, supra note 32, at 155; see also Barnett, Chickens \& Eggs, supra note 32, at 634-35 ("[T] he more different modes of analysis that point in the same direction the more certain we can be that the results of our analysis are correct.").

238 Cf. Heald \& Heald, supra note 145, at 1166 ("If common law rules arise from custom, ... then it would not be surprising to find that the common law and community norms seldom diverge."); Ellickson, supra note 68, at 75 ("I regard it as more plausible in this instance that norms had influenced law than vice versa."). 
its origin, I suggest that the correspondence between common sense and common law is no coincidence. 